\title{
Automatic weaning based on individual solid feed intake: Effects on behavior and performance of dairy calves
}

\author{
J. B. Benetton, H. W. Neave, J. H. C. Costa, ${ }^{*}$ M. A. G. von Keyserlingk, and D. M. Weary† \\ Animal Welfare Program, Faculty of Land and Food Systems, University of British Columbia, Vancouver, BC, Canada V6T $1 Z 4$
}

\section{ABSTRACT}

Calves are typically weaned from milk to solids once they reach a predetermined age or when they are consuming a predetermined intake of solids. The first aim of this study was to compare feeding behavior and performance of calves weaned based on age versus starter intake. The latter method can result in considerable variation in the age at which calves are weaned, so a secondary aim was to compare calves that weaned early or late when weaned based on starter intake. In experiment 1 , dairy calves were randomly assigned to be either (1) weaned by age at d $70(n=16)$, or $(2)$ weaned by intake, where calves were weaned based on starter intake $(\mathrm{n}=16)$. All calves were fed using an automatic milk feeder and offered $12 \mathrm{~L} / \mathrm{d}$ of milk until $30 \mathrm{~d}$ of age. On d 31, all calves had their milk rations reduced. Calves weaned by age were reduced to $6 \mathrm{~L} / \mathrm{d}$ of milk over $5 \mathrm{~d}$ and received $6 \mathrm{~L} / \mathrm{d}$ milk from d 35 until d 63 , when milk was reduced over $7 \mathrm{~d}$ until complete weaning at $\mathrm{d} 70$. For calves weaned by intake, the milk ration was reduced on d 31 to $75 \%$ of that calf's previous milk intake (3-d average) and further reduced by $25 \%$ when the calf met each of 3 targets for starter intake: 225, 675 , and $1,300 \mathrm{~g} / \mathrm{d}$. Calves that failed to reach the final target by d 63 (failed-intake group; $\mathrm{n}=6$ ) were weaned over $7 \mathrm{~d}$ to complete weaning at $\mathrm{d} 70$. Ten calves met all 3 starter intake targets (successful-intake group). In experiment 2, all calves were assigned to the weaned-byintake treatment $(\mathrm{n}=48)$. The weaning strategy was identical to that described for experiment 1 , but calves were permitted up to $\mathrm{d} 84$ to reach the final starter intake target. Forty-three calves met all 3 targets and were retrospectively divided into early-weaning (weaned before $\mathrm{d} 63 ; \mathrm{n}=31$ ) and late-weaning (weaned on or after $\mathrm{d} 63 ; \mathrm{n}=12$ ) categories. In both experiments, the weaning period was considered from the time of initial

Received October 11, 2018.

Accepted February 4, 2019.

${ }^{*}$ Current address: Department of Animal and Food Sciences, University of Kentucky, Lexington, KY 40546.

†Corresponding author: dan.weary@ubc.ca milk reduction at $\mathrm{d} 31$ until complete weaning at $\mathrm{d} 70$ (weaned by age) or when consuming 1,300 g/d (weaned by intake). Postweaning growth was monitored from weaning until final weight in the calf-rearing period at d 98 (experiment 1) and d 105 (experiment 2). Final weight in the grower period was measured at d 134 (experiment 1) and d 145 (experiment 2). In experiment 1, successful-intake calves (vs. calves weaned by age) consumed $125.3 \pm 16.4 \mathrm{~L}$ less milk and $41.3 \pm 9.3 \mathrm{~kg}$ more starter over the experimental period, engaged in more unrewarded visits to the milk feeder during weaning $(11.1 \pm 1.5$ vs. $5.0 \pm 1.3$ visits $/ \mathrm{d})$, and achieved similar weights at the end of the grower period (188.2 \pm 6.6 vs. $195.2 \pm 5.7 \mathrm{~kg}$ ). In experiment 2 , calves that weaned by intake early (vs. late) consumed $93.3 \pm 26.0 \mathrm{~L}$ less milk and $57.2 \pm 12.2 \mathrm{~kg}$ more starter, engaged in a similar number of unrewarded visits during weaning $(7.0 \pm 0.6$ vs. $7.6 \pm 1.0$ visits/d), had greater average daily gain during weaning $(1.08 \pm 0.02$ vs. $0.94 \pm 0.03 \mathrm{~kg} / \mathrm{d})$, and achieved greater final weights at the end of the grower period $(203.2 \pm 2.9$ vs. $192.6 \pm 4.2 \mathrm{~kg})$. These results indicate that calves weaned based on starter intake can achieve similar weights to those weaned by age, despite consuming less milk. However, some calves will fail to meet starter intake targets unless given sufficient time to do so. Variation in preweaning feed intake provides an opportunity for individualized management of calves. Key words: precision dairy farming, robotic milk feeders, step-down weaning, calf growth

\section{INTRODUCTION}

Dairy calves fed high allowances of milk and weaned abruptly (conventionally) from milk to solids often consume little solid feed (typically calf starter) before weaning and thus can experience poor growth (e.g., Jasper and Weary, 2002) and prolonged hunger around weaning (e.g., de Passillé et al., 2011). To address this issue, gradual weaning techniques have been used to increase starter intakes of calves before weaning (reviewed by Khan et al., 2016). One technique, the step-down of milk allowance at around $4 \mathrm{wk}$ of age, can increase starter intake before weaning and help to maintain $\mathrm{BW}$ 
during and after weaning when calves are fed high milk allowances (Khan et al., 2007a; Omidi-Mirzaei et al., 2015; Khani et al., 2017).

Even with the use of a step-down weaning program, there can be variability in starter intakes. In seminatural environments, the timing of the transition from milk to solid food is highly variable among individuals. One study on extensively managed cattle reported that weaning age ranged from 7 to 14 mo (Reinhardt and Reinhardt, 1981). Studies have also reported variability in intensively managed calves. For instance, Heinrichs and Heinrichs (2011) found that in 795 heifers, the age to consume $0.91 \mathrm{~kg}$ of starter had a $27 \%$ coefficient of variance $(70.5 \pm 19.8 \mathrm{~d}$, mean $\pm \mathrm{SD})$. de Passillé and Rushen (2016) reported that calves first consumed $0.2 \mathrm{~kg} / \mathrm{d}$ of starter between 23 and $82 \mathrm{~d}$ of age and first consumed $1.4 \mathrm{~kg} / \mathrm{d}$ of starter at between 58 and $94 \mathrm{~d}$ of age when fed $12 \mathrm{~L} / \mathrm{d}$ of milk throughout the milk-feeding period. Calves offered restricted milk allowances typically began to consume more starter at an earlier age but still needed from 45 to $98 \mathrm{~d}$ to consume $2 \mathrm{~kg} / \mathrm{d}$ of starter when fed $6 \mathrm{~L}$ of milk/d (Roth et al., 2009). Similarly, Neave et al. (2018) reported large variability in age ( 8 to $41 \mathrm{~d}$ ) to first find and consume 40 $\mathrm{g}$ of starter in calves fed a range $(6$ to $12 \mathrm{~L} / \mathrm{d})$ of milk allowances.

This variability in when calves begin to consume starter suggests that individuals will vary in how well they cope with early weaning. With a movement toward individual-based and data-driven farm management (see review by Rutten et al., 2013), there are more opportunities to manage weaning at the individual level. Roth et al. (2008, 2009), and de Passillé and Rushen (2016) demonstrated how automated milk and concentrate feeders could be used to wean calves individually when starter intake reached specific targets. In both studies, the authors compared individualized weaning based on starter intakes with weaning programs based on age and found similar or improved weights after weaning; however, weaning ages of calves weaned based on starter intake were variable, ranging from 45 to 98 d (Roth et al., 2009) and from 58 to 94 d (de Passillé and Rushen, 2016).

Stepping down the milk ration during the milk-feeding period can encourage starter intake (Khan et al., 2007a) but, to our knowledge, no study has investigated weaning based on starter intake following an initial milk step-down. Thus, the aim of our experiment 1 was to compare feeding behavior and weight gains of calves enrolled on 2 weaning programs using a step-down milk reduction: a traditional weaning program based on age and a weaning program based on individual starter intake.
One interesting outcome of experiment 1 was that not all calves were able to wean based on starter intake before 9 wk of age. Several studies have shown a wide range in weaning ages when calves were permitted ample time (up to 10.5 wk; de Passillé and Rushen, 2012) or unlimited time (Roth et al., 2009; de Passillé and Rushen, 2016) to achieve specific starter intake targets. A growing body of evidence indicates that earlier weaning age and greater weaning DMI are associated with improved first-lactation milk yield (Heinrichs and Heinrichs, 2011; Gelsinger et al., 2016), suggesting that individuals able to wean early with high starter intake may fare well on farms. However, no research has investigated the feeding behavior and performance of calves that consume specific starter intake amounts (and hence "self-wean") earlier versus later. Thus, the aim of experiment 2 was to offer an extended period (up to $12 \mathrm{wk}$ ) for calves to achieve the specified starter intake targets outlined in experiment 1 . We specifically compared the feeding behavior and weight gains of calves that met these starter intake targets before ("early") and after ("late") 9 wk of age (the cut off identified in experiment 1).

\section{MATERIALS AND METHODS}

Experiment 1 was conducted from January to August 2017 and experiment 2 from July 2017 to April 2018 at the University of British Columbia (UBC) Dairy Education and Research Centre (Agassiz, BC, Canada). The animals were cared for according to the guidelines of the Canadian Council of Animal Care (2009), with animal use approved by the UBC Animal Care Committee (protocol \# A14-0245).

\section{Experiment 1}

Animals and Housing. Thirty-two Holstein female calves were used in this experiment. Calves were separated from their dams at birth, weighed (mean $\pm \mathrm{SD}$, $38.7 \pm 5.7 \mathrm{~kg})$, and fed $4 \mathrm{~L}$ of colostrum $(>50 \mathrm{~g} / \mathrm{L}$ of $\operatorname{IgG}$ ) by bottle within $6 \mathrm{~h}$ of birth in individual pens bedded with sawdust. A blood sample was collected from the jugular vein $2 \mathrm{~h}$ after the first feeding of colostrum, and serum was analyzed using a Reichert AR 200 Digital Handheld Refractometer (Reichert, Depew, $\mathrm{NY}$ ). All calves had serum total protein levels $>5.2 \mathrm{~g} /$ $\mathrm{dL}$ (as recommended for passive transfer of immunity; Windeyer et al., 2014). Calves were bottle-fed $8 \mathrm{~L} / \mathrm{d}$ of whole milk divided into 2 feedings while individually housed. Calves were sedated (Rompun, 2\%; Bayer Inc., Mississauga, ON, Canada; $0.25 \mathrm{mg} / \mathrm{kg}$ of $\mathrm{BW}$ ) and disbudded using caustic paste (Dr. Naylor's Dehorning 
Paste; H. W. Naylor Company Inc., Morris, NY) at 4 $\mathrm{d}$ and moved to sawdust-bedded group pens $(4.87 \times$ $7.31 \mathrm{~m}$ ) of 8 calves each at 6 to $9 \mathrm{~d}$ of age (nominally $\mathrm{d} 7$ : mean $7.5 \pm 1.1 \mathrm{~d}$ ). Calves were added to groups in chronological order according to their birth date. Once group size reached 8, a new group was started until all 32 calves (4 groups) were enrolled.

Calves in the group pen had access to pasteurized whole milk through an automated milk feeder (CF 1000 CS Combi; DeLaval Inc., Tumba, Sweden). Each pen had one milk feeder equipped with one teat, and starter was offered ad libitum (Calf starter, Trouw Nutrition, Chilliwack, BC, Canada) from the same computerized feeder used for milk. Each automated feeder was separated by a metal barrier and allowed one calf to feed at a time (for further details regarding the automated feeder configuration, see Rosenberger et al., 2017). The milk and grain feeders recorded intake at each visit, and the milk feeder recorded the number of rewarded visits (permitted to drink milk) and unrewarded visits (not permitted to drink milk). Farm hay and water were available ad libitum from automatic feeders (RIC; Insentec B.V., Marknesse, the Netherlands) located next to the milk and starter intake feeders. Hay intake could not be reliably measured throughout the experiment and thus is not reported. Calibration of all automated feeders was performed every second week for each group pen to verify accurate dispensing and intake of milk and grain portions.

Calves remained in the group pen until the last calf in each group completed the calf-rearing period (d 98 of age); then, the entire group was transported to the grower facility (located on the same farm as the calfrearing facility), where calves were maintained in the same group of 8 that they were raised in until completion of the experiment at $134 \mathrm{~d}$ of age. Calves were fed ad libitum farm hay and concentrate from 2 automatic feeders (RIC; Insentec B.V.) and ad libitum water from a water trough at the center of the pen.

Milk samples were collected and analyzed once a week for components at Pacific Milk Analysis Laboratory (Chilliwack, BC, Canada) using mid-infrared spectrometry following International Organization for Standardization guidelines (ISO, 2013). Calf starter and hay samples were collected weekly, frozen, and pooled into monthly samples just before analysis. Nutrient and DM analysis (wet chemistry) were performed at Cumberland Valley Analytical Services (Waynesboro, $\mathrm{PA}$ ). Samples were oven-dried at $55^{\circ} \mathrm{C}$ for $48 \mathrm{~h}$, ground to pass through a 1-mm screen, and then analyzed for ADF (AOAC International, 2000, method 973.18), NDF with heat-stable $\alpha$-amylase and sodium sulfite (Van Soest et al., 1991), and CP $(\mathrm{N} \times 6.25$; AOAC International, 2000, method 990.03; Leco FP-528 Ni- trogen Analyzer, Leco, St. Joseph, MI). Milk and solid feed nutrient analyses are reported in Table 1.

Experimental Design and Treatments. When moved to the group pen, calves were pseudo-randomly allocated to 1 of 2 weaning treatments: weaning by age (at d 70) or weaning by intake, in which calves were weaned based on their starter intake $(\mathrm{n}=16$ calves in each treatment), with the constraint that each group of 8 calves contained 4 calves of each treatment balanced for birth weight. For the weaning-by-age treatment, calves were offered $12 \mathrm{~L} / \mathrm{d}$ of milk from arrival in the group pen until d 30, and milk was reduced by $1.2 \mathrm{~L} / \mathrm{d}$ over $5 \mathrm{~d}$ such that at $\mathrm{d} 35$ calves were provided $6 \mathrm{~L} / \mathrm{d}$. This milk ration was continued until d 63 , when milk was reduced by approximately $0.86 \mathrm{~L} / \mathrm{d}$ over $7 \mathrm{~d}$ such that calves were fully weaned at $\mathrm{d} 70$. For the weaningby-intake treatment, calves were offered $12 \mathrm{~L} / \mathrm{d}$ of milk from arrival in the group pen until d 30. Milk allowance was reduced on d 31 to $75 \%$ of the individual's average milk intake over the previous $3 \mathrm{~d}$, and milk was further reduced by $25 \%$ when each calf achieved specific daily starter intake targets of 225,675 , and $1,300 \mathrm{~g} / \mathrm{d}$ (complete weaning). These targets correspond approximately to the $0.5,1.5$, and $3 \mathrm{lb}$. of starter intake targets recommended by the Bovine Alliance on Management and Nutrition (2017). To qualify for the milk reduction, calves needed to consume the target rolling average intake across the preceding $3 \mathrm{~d}$, with a daily minimum of $50 \%$ of the target. If a calf did not reach the final target by d 63 , it was gradually weaned by reducing the milk allowance by one-seventh per day until fully weaned at d 70. After transfer to the grower facility, calves were maintained in the same group of 8 that they were raised in, with 4 calves of each treatment in each group, until completion of the experiment at $134 \mathrm{~d}$ of age.

Data Collection and Health. Calves were individually weighed and assessed for health on a weigh scale twice a week, and body measurements were taken once a week during the calf-rearing period (up to d 98). Health examinations and body measurements were not performed during the grower period (d 99 to 134). Body measurements were taken as described by Khan et al. (2007b), including hip and withers heights, body length, hip width, heart girth, and body barrel. Health examinations were performed to control for the effect of illness on outcome measures (health was not considered an outcome measure); examinations followed Costa et al. (2015), consisting of diarrhea scoring while on the individual weigh scale, where $1=$ normal feces; $2=$ plaques but not watery; 3 = watery and body temperature $<39.5^{\circ} \mathrm{C} ; 4=$ watery and body temperature $\geq 39.5^{\circ} \mathrm{C}$. Calves with a score of 4 were treated following the standard farm protocol with electrolytic solutions (Hydrafeed, EXL Laboratories, Minneapolis, MN), and 
Table 1. Mean $( \pm \mathrm{SD})$ chemical composition of milk, calf starter, and hay on a DM basis (\% unless otherwise noted) offered to Holstein dairy calves in experiment $1(\mathrm{n}=32)$ and experiment $2(\mathrm{n}=48)$

\begin{tabular}{|c|c|c|c|}
\hline Variable & Milk $^{1}$ & Calf starter ${ }^{2}$ & $\mathrm{Hay}^{3}$ \\
\hline \multicolumn{4}{|l|}{ Experiment 1} \\
\hline $\mathrm{DM}$ & $12.2 \pm 0.96$ & $86.0 \pm 0.8$ & $84.5 \pm 3.1$ \\
\hline $\mathrm{CP}$ & $28.5 \pm 1.8$ & $20.9 \pm 0.8$ & $15.6 \pm 1.5$ \\
\hline Fat & $33.1 \pm 2.0$ & $5.1 \pm 0.6$ & $\mathrm{ND}^{4}$ \\
\hline Lactose & $32.4 \pm 2.2$ & ND & ND \\
\hline $\mathrm{NDF}$ & ND & $17.5 \pm 0.8$ & $58.9 \pm 2.3$ \\
\hline $\mathrm{ADF}$ & ND & $9.7 \pm 0.4$ & $34.6 \pm 1.4$ \\
\hline Starch & ND & $37.3 \pm 1.7$ & ND \\
\hline Ash & ND & $7.0 \pm 0.4$ & $8.1 \pm 0.5$ \\
\hline $\mathrm{ME}^{5}(\mathrm{Mcal} / \mathrm{kg})$ & $5.4 \pm 0.22$ & $3.1 \pm 0.02$ & $2.0 \pm 0.06$ \\
\hline \multicolumn{4}{|l|}{ Experiment 2} \\
\hline $\mathrm{DM}$ & $12.5 \pm 0.57$ & $86.5 \pm 1.2$ & $83.1 \pm 2.2$ \\
\hline $\mathrm{CP}$ & $27.5 \pm 1.5$ & $21.0 \pm 1.2$ & $16.0 \pm 2.5$ \\
\hline Fat & $32.6 \pm 1.5$ & $5.6 \pm 0.7$ & ND \\
\hline Lactose & $32.1 \pm 1.4$ & ND & ND \\
\hline $\mathrm{NDF}$ & ND & $18.3 \pm 1.6$ & $58.1 \pm 1.7$ \\
\hline $\mathrm{ADF}$ & ND & $10.1 \pm 0.8$ & $34.0 \pm 1.9$ \\
\hline Starch & ND & $37.3 \pm 2.5$ & ND \\
\hline Ash & ND & $6.9 \pm 0.6$ & $8.4 \pm 0.7$ \\
\hline ME (Mcal/kg) & $5.6 \pm 0.07$ & $3.1 \pm 0.03$ & $2.1 \pm 0.08$ \\
\hline
\end{tabular}

${ }^{1}$ Pasteurized whole milk storage tank samples $(\mathrm{n}=21)$.

${ }^{2}$ Medicated starter, $44 \mathrm{mg} / \mathrm{kg}$ of monensin (Trouw Nutrition, Chilliwack, BC, Canada).

${ }^{3}$ Mixture of farm hay: festulolium [tall fescue (Festuca arundinacea) $\times$ ryegrass (Lolium perenne L.) cross], orchard grass (Dactylis glomerata L.), and ryegrass (Lolium perenne L.).

${ }^{4} \mathrm{ND}=$ not determined.

${ }^{5} \mathrm{ME}=\mathrm{TDN} \times 0.04409 \times 0.82 ;$ calculated according to NRC $(2001)$ equations

calves failing to respond to treatment within $2 \mathrm{~d}$ were administered a nonsteroidal anti-inflammatory drug (NSAID; $20 \mathrm{mg} / \mathrm{mL}$ Metacam; Boehringer Ingelheim, Burlington, ON, Canada). Clinical examinations of respiratory health were performed by lung auscultation $(0=$ no lung consolidation detected; $1=$ some lung consolidation; 2 = lung consolidation); calves showing nasal discharge and pathological sounds of pulmonary infection (score of 2) were treated with antibiotic drugs (Resflor GOLD, Intervet Inc., Roseland, NJ, or Draxxin, Zoetis Inc., Parsippany, NJ). Although it is possible that illnesses went undetected, the twice-weekly health checks captured most events, given that calves show changes in feeding behavior $4 \mathrm{~d}$ before clinical diagnosis and take 7 to $10 \mathrm{~d}$ to return to normal behavior (Knauer et al., 2017). We also performed twice-daily visual examinations (morning and afternoon) of all calves in the pen; any calves that were seen to have diarrhea or ill thrift (unresponsive to human presence at the front of the pen, head or ears down) were examined further, following the above health examination procedure, and treatments were administered as necessary.

Final weight for the calf-rearing period was taken at d 98 of age. Calves were weighed upon arrival at the grower facility (nominally wk 15; mean \pm SD, $109.0 \pm$ $10.6 \mathrm{~d}$ of age), 2 wk after arrival (nominally wk $17 ; 123.5$ $\pm 11 \mathrm{~d}$ of age), and 4 wk after arrival (nominally wk 19; $134.4 \pm 11.7 \mathrm{~d}$ of age). Final weight for the grower pe- riod was taken 4 wk after arrival at the grower facility (d 134 of age). Because of an issue with the weigh scale for group 3 at final weight measurement, this group was excluded from the analysis for this variable.

\section{Experiment 2}

Animals and Housing. Forty-eight Holstein calves (45 females and 3 males) were enrolled. Calves were required to remain with their dam for $5 \mathrm{~h}$ after birth. Calves were then separated, weighed (mean \pm $\mathrm{SD}, 40.3 \pm 5.9 \mathrm{~kg}$ ), and moved into individual pens, where all feeding and blood sampling procedures were as described for experiment 1 . All calves achieved serum total protein concentrations $>5.2 \mathrm{~g} / \mathrm{dL}$. At d 1 of age and before receiving their second milk meal, calves entered the group pen based on birth order until each pen contained 8 calves. All procedures after moving to the group pen were identical to those in experiment 1 , except that calves were disbudded using a hot iron at approximately 2 wk of age. All calves received sedation (Rompun $2 \%, 0.25 \mathrm{mg} / \mathrm{kg}$ of BW; Bayer Inc.) and a local anesthetic ( $2 \%$ lidocaine, $4 \mathrm{~mL}$ per side; Averst Veterinary Labs, Guelph, ON, Canada) applied subcutaneously to the cornual nerve of each horn bud before the procedure, and received an NSAID $(20 \mathrm{mg} / \mathrm{mL}$ Metacam, $0.5 \mathrm{mg} / \mathrm{kg}$ of $\mathrm{BW}$; Boehringer Ingelheim) immediately after and $24 \mathrm{~h}$ after the procedure. All 
calves remained in the group pen until the last calf of each group completed the calf-rearing period at d 105 of age. Calves were transported to the grower facility and housed and fed as described in experiment 1 until completion of the experiment at d 145 of age.

Experimental Design. All calves were weaned by intake based on individual starter intake. Calves were offered up to $12 \mathrm{~L} / \mathrm{d}$ of milk in the group pen until nominally d 30 (mean $31.3 \pm 1.15 \mathrm{~d}$ ). Calves were weaned as described for the weaned-by-intake treatment in experiment 1 , except that calves were permitted an extended period of time (up to d 84) to reach the final starter intake target $(1,300 \mathrm{~g} / \mathrm{d}$ of starter $)$; if a calf did not reach this target by d 84, the calf was weaned by reducing the calf's milk allowance by one-seventh per day for $7 \mathrm{~d}$, such that weaning was completed by d 91. After transfer to the grower facility, calves were maintained in the same group of 8 that they were raised in until d 145 of age.

Data Collection and Health. All data collection, health examination procedures, and treatment protocols were identical to those in experiment 1 . Health examinations and body measurements were not performed during the grower period (d 106 to 145). Final weight for the calf-rearing period was taken at d 105 of age. Calves were weighed upon arrival at the grower facility (nominally wk 16; mean \pm SD: $117.1 \pm 8.6 \mathrm{~d}$ of age), 2 wk after arrival (nominally wk $18 ; 130.7 \pm 8.1 \mathrm{~d}$ of age), and 4 wk after arrival (nominally wk 20; 144.6 $\pm 8.0 \mathrm{~d}$ of age). Final weight for the grower period was taken 4 wk after arrival at the grower facility (d 145 of age).

\section{Statistical Analysis}

The sample sizes for experiments 1 and 2 were selected based on a power analysis to detect a difference of $150 \mathrm{~g} / \mathrm{d}(\mathrm{SD}=0.15)$ in ADG between treatments (power $=0.80, \alpha=0.05$ ), using data from Rosenberger et al. (2017). In experiment 2, we expected that between 30 and $40 \%$ of calves would wean after 9 wk of age, based on data from de Passillé and Rushen (2016). All analyses were performed in SAS software (version 9.4; SAS Institute Inc., Cary, NC), with calf as the experimental unit (data deposited in repository: Benetton et al., 2019). Data were scrutinized using the UNIVARIATE procedure and probability distribution plots for normality; only preweaning starter DMI was not normally distributed and thus square root transformed.

Calves were classified as sick if they had a score $\geq 3$ for diarrhea, had a score of 2 for lung consolidation, were treated with NSAID or antibiotics, or had any combination of the above at any point during the experiment. Four calves in experiment 1 (1 failed-intake calf and 1 successful-intake calf treated for respiratory infection with antibiotics; 1 successful-intake calf treated for respiratory infection and fever with antibiotics and NSAID, and 1 weaned-by-age calf treated for fever with NSAID) and 14 calves in experiment 2 (7 earlyweaning, 5 late-weaning, and 2 failed-weaning calves were treated for respiratory infection with antibiotics, diarrhea with electrolytes, and (or) fever with NSAID) received medical treatments during the experiment. Two calves in experiment 2 required multiple antibiotic treatments and were removed from the experiment.

In experiment 1 , the weaned-by-intake calves were retrospectively divided into 2 weaning outcomes: successful intake (i.e., met the final starter intake target by $\mathrm{d} 63 ; \mathrm{n}=10$ ) or failed intake (i.e., did not meet the final starter intake target; $\mathrm{n}=6$ ). We predicted that the effect of treatment would vary depending upon the outcome for calves in the weaned-by-intake treatment (i.e., successful versus failed intake); thus our model compared calves weaned by age with those weaned by intake separately by outcome of the intake treatment (i.e., successful or failed) using specified contrasts, and results are reported as $t$-statistics. Data for feed intake, feeding behavior, and growth and body measures were summarized into 5 periods: preweaning (d 7 to 30 ), weaning (d 31 to 69 ), postweaning (d 70 to 98 ), total calf rearing (d 7 to 98), and grower (d 99 to 134).

In experiment 2 , weaned-by-intake calves were retrospectively divided into 3 weaning outcomes: (1) early (met the final target by d $63, \mathrm{n}=31$ ), and (2) late (met the final target after d 63 and before d $84, \mathrm{n}=12$ ), or (3) failed (did not meet any targets before d 84, n $=3$ ). Because of the low sample size, the failed calves in experiment 2 were excluded from further analyses, resulting in 43 calves in the final analysis. Calves that weaned by intake before 9 wk (early) were compared with those weaned by intake after 9 wk of age (late). We detected no differences between analyses with and without the 3 male calves, so we retained calves of both sexes in the final analyses. Data for feed intake, feeding behavior, and growth and body measures were summarized into 5 periods: preweaning (d 1 to 30 ), weaning (d 31 to 91 ), postweaning (d 92 to 105), total calf rearing (d 1 to 105), and grower (d 106 to 145).

For experiments 1 and 2, the MIXED procedure of SAS (SAS Institute Inc.) was used to test the effects of weaning treatment and outcome on the following response variables separately by period: feed intake (milk and starter DMI), feeding behaviors (rewarded and unrewarded visits to the milk feeder), body measurements (rate of change and final measures of hip height, withers height, body length, hip width, heart girth, and body barrel), ADG, and final weight. We also analyzed the effect of weaning treatment and outcome on ADG and 
final weight in the grower period. All models included the fixed effects of birthweight, order of introduction to the group pen (i.e., birth order), and sickness (dichotomous variable, sick or not sick during the experiment), with group specified as a random effect. The models for the grower period also included age as a fixed effect. Results are reported as least squares means and standard errors for each period and weaning outcome. Significance was declared at $P \leq 0.05$ and tendencies at $\leq 0.1$.

Finally, for descriptive purposes, we graphed weekly milk and starter intakes and BW for calves in the weaning outcomes weaned by age, successful intake, and failed intake in experiment 1 , and for calves that weaned early and late in experiment 2.

\section{RESULTS}

\section{Experiment 1}

Descriptive Results: Age and Duration of Weaning. Six $(37.5 \%)$ of the calves in the weaned-byintake treatment failed to meet the final starter intake target (failed intake); 2 of these calves did not meet any target, 3 calves met only the first target of $225 \mathrm{~g} / \mathrm{d}$, and 1 met the second target $(675 \mathrm{~g} / \mathrm{d})$. The mean $( \pm \mathrm{SD})$ weaning age for the successful-intake calves was $52 \pm$ $6.1 \mathrm{~d}$ (range: 40 to $62 \mathrm{~d}$ ), almost 3 wk before the age set for the weaned-by-age treatment. For these successfulintake calves, the time from when the first starter intake target of $225 \mathrm{~g} / \mathrm{d}$ was reached to complete weaning at $1,300 \mathrm{~g} / \mathrm{d}$ averaged $11.8 \pm 4.3 \mathrm{~d}$. Milk allowances after the initial step-down on $\mathrm{d} 31$ for successful-intake (5.4 $\pm 0.8 \mathrm{~L} / \mathrm{d})$ and failed-intake $(6.4 \pm 1.3 \mathrm{~L} / \mathrm{d})$ calves were similar to the set step-down milk allowance of $6 \mathrm{~L} / \mathrm{d}$ for weaned-by-age calves. Weekly milk intake, starter intake, and BW for weaned-by-age, successful-intake, and failed-intake calves are illustrated for descriptive purposes in Figure 1.

Milk Intake. For weaned-by-age calves, milk intakes followed the pattern expected based on the step-down weaning protocol (Figure 1a). We observed large individual variability in preweaning milk intake for weaned-by-age calves (mean: $8.5 \mathrm{~L} / \mathrm{d}$, range: 6.2 to 11.0 L/d), successful-intake calves (mean: $8.2 \mathrm{~L} / \mathrm{d}$, range: 6.2 to $9.9 \mathrm{~L} / \mathrm{d}$ ), and failed-intake calves (mean: $8.6 \mathrm{~L} / \mathrm{d}$, range: 6.6 to $10.8 \mathrm{~L} / \mathrm{d}$; Supplemental Figure S1; https: //doi.org/10.3168/jds.2018-15830). Milk consumption was lower for the successful-intake calves starting after 4 wk of age, but milk intakes for the failed-intake calves were similar to those in the weaned-by-age treatment. Given that milk intakes were lower for the successfulintake calves during much of the milk-feeding period, cumulative milk DMI was much less (by about $14 \mathrm{~kg}$ ) for these calves compared with both failed-intake $\left(t_{1,23}\right.$ $=5.1, P<0.001)$ and weaned-by-age calves $\left(t_{1,23}=7.6\right.$, $P<0.001$; Table 2). Milk intakes did not differ between treatments in the preweaning period.

Rewarded and Unrewarded Visits. During the preweaning period, rewarded visits to the milk feeder were similar between weaned-by-age, successful-intake, and failed-intake calves (Table 2). However, during the weaning period, successful-intake calves had about half as many rewarded visits to the milk feeder as failedintake calves $\left(t_{1,23}=3.7, P<0.01\right)$ and weaned-by-age calves $\left(t_{1,23}=6.7, P<0.001\right)$, averaging 3 versus 6 and 7 visits/d, respectively. We found a similar difference when considering the total calf-rearing period $\left(t_{1,23}>\right.$ $2.2, P<0.03)$.

Across the total calf-rearing period, the number of unrewarded visits to the milk feeder was highest for successful-intake calves compared with failed-intake calves $\left(t_{1,23}=3.0, P<0.01\right)$ and those weaned by age $\left(t_{1,23}=3.0, P<0.01\right)$. This difference was especially pronounced during weaning, where successful-intake calves had more than twice as many unrewarded visits as failed-intake calves $\left(t_{1,23}=3.4, P<0.01\right)$ and weaned-by-age calves $\left(t_{1,23}=3.5, P<0.01\right)$, averaging 11 versus 3.5 and 5 visits/d, respectively. In the preweaning period, we found no differences in the number of unrewarded visits by weaning treatment or outcome.

Starter Intake. Weekly starter intake increased with calf age, starting especially at wk 5 for the successful-intake calves and wk 8 for failed-intake and weaned-by-age calves (Figure 1b). During the preweaning period, the successful-intake calves consumed twice as much starter as the failed-intake calves $\left(t_{1,23}=1.7\right.$, $P=0.06)$ and weaned-by-age calves $\left(t_{1,23}=1.9, P=\right.$ $0.09)$; these calves also consumed more than twice as much starter during weaning as failed-intake $\left(t_{1,23}=\right.$ 5.7, $P<0.001)$ and weaned-by-age calves $\left(t_{1,23}=6.0, P\right.$ $<0.001$; Table 2). This difference was also evident over the total calf-rearing period $\left(t_{1,23}>4.2, P<0.001\right)$. There were no differences in intakes after weaning by weaning treatment or outcome.

Growth During the Total Calf-Rearing Period. Calf BW increased over time, with few differences between weaning methods or outcomes until around wk 8 , when failed-intake calves had the lowest BW for the remainder of the calf-rearing period (Figure 1c). Failed-intake calves had the lowest ADG during weaning (vs. successful-intake calves: $t_{1,23}=2.6, P=0.01$; vs. weaned-by-age calves: $t_{1,23}=1.8, P=0.09$ ) and a reduced final weight $(\sim 11 \mathrm{~kg}$ lower $)$ at the end of the calf-rearing period (d 98 of age) compared with successful-intake $\left(t_{1.23}=1.8, P=0.09\right)$ and weaned-by-age calves $\left(t_{1,23}=2.1, P=0.05\right.$; Table 3$)$. Successful-intake calves had similar ADG during weaning and similar 

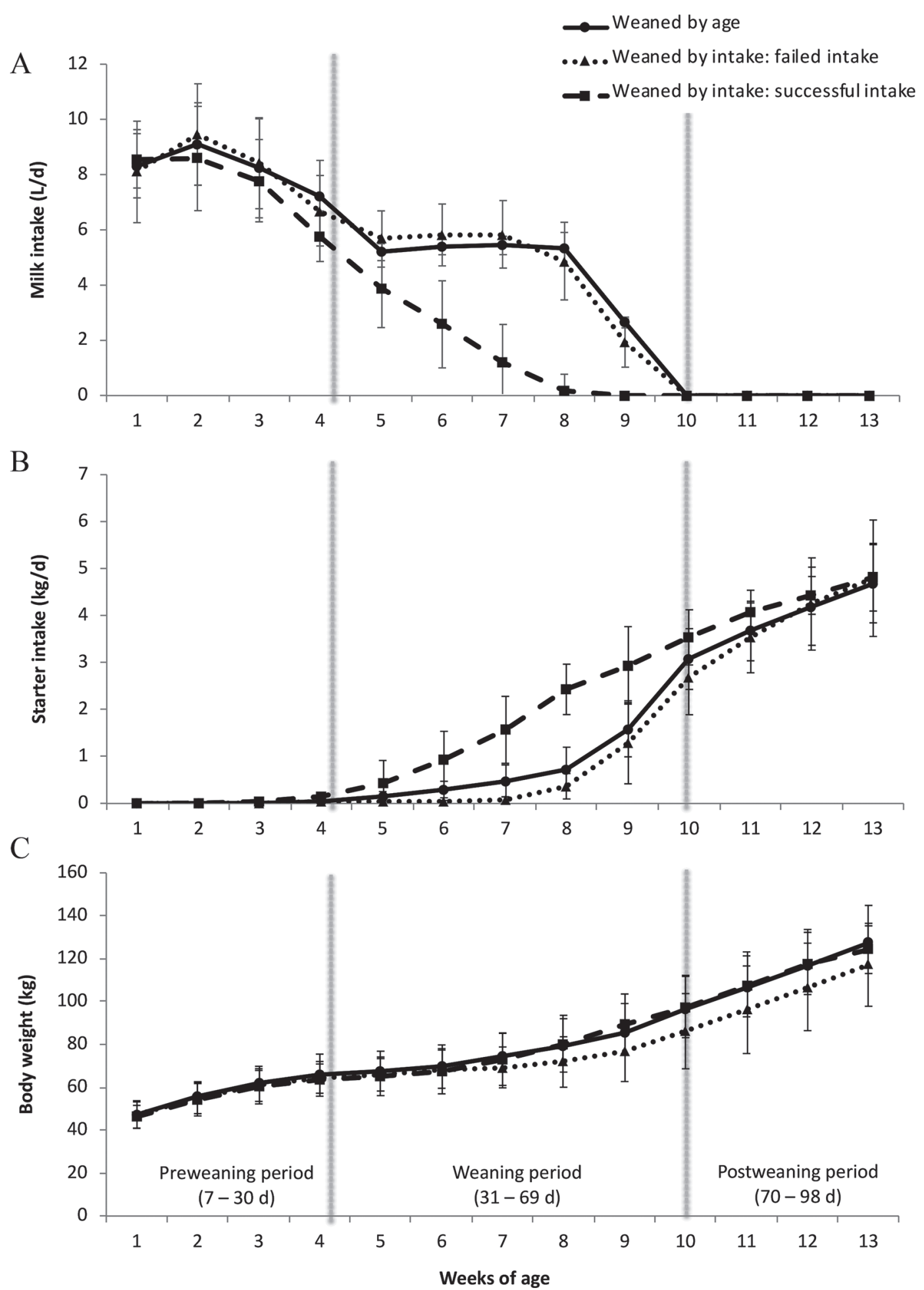

Figure 1. Experiment 1: arithmetic means $( \pm \mathrm{SD})$ for descriptive purposes of $(\mathrm{A})$ milk intake, $(\mathrm{B})$ starter intake, and $(\mathrm{C})$ BW for Holstein calves aged 1 to $13 \mathrm{wk}$. Values are shown separately for calves weaned by age $(\mathrm{n}=16)$ and calves weaned by intake $(\mathrm{n}=16)$; the latter group was divided into calves that failed to wean by intake before 9 wk of age $(\mathrm{n}=6)$ and calves that successfully weaned by intake $(\mathrm{n}=10)$. All calves received $12 \mathrm{~L} / \mathrm{d}$ until wk 4 . Weaned-by-age calves were reduced to $6 \mathrm{~L} / \mathrm{d}$ of milk from wk 4 to 5 , and then by $20 \% / \mathrm{d}$ from wk 9 to 10 until complete weaning at wk 10 . The milk allowance of calves weaned by intake was reduced by $25 \%$ of each individual's milk allowance at wk 4 , and then a further $25 \%$ when each calf reached each target of starter intake $(225,675$, and 1,300 g/d) until complete weaning at 1,300 g/d of calf starter. Failed-intake calves were forced to wean over a 7 -d period by $10 \mathrm{wk}$. 
final weight at the end of the calf-rearing period (d 98 of age) compared with those in the weaned-by-age treatment.

Daily body measurement growth showed few differences between weaning treatments and outcomes during the preweaning period, except that failed-intake calves tended to have improved withers height growth compared with successful-intake calves $\left(t_{1,16}=1.9, P=\right.$ $0.07)$ and weaned-by-age calves $\left(t_{1,16}=1.8, P=0.09\right.$; Table 3). During weaning, failed-intake calves had (or tended to have) decreased hip height, heart girth, and body barrel compared with successful-intake calves $\left(t_{1,23}>1.8, P<0.09\right)$ and weaned-by-age calves $\left(t_{1,23}\right.$ $>2.1, P<0.05)$. Calves generally had similar body growth measures during the postweaning period, except that successful-intake calves tended to have greater body length $\left(t_{1,23}=2.0, P=0.06\right)$ and body barrel growth $\left(t_{1.23}=2.3, P=0.03\right)$ compared with failedintake calves, translating into differences in final body measures at the end of the calf-rearing period; failedintake calves had (or tended to have) lower hip width and heart girth than successful-intake $\left(t_{1,21}>2.1, P<\right.$ $0.04)$ and weaned-by-age calves $\left(t_{1,21}>1.7, P<0.10\right)$ and lower hip height and body length than weaned-byage calves $\left(t_{1,23}>1.8, P<0.09\right)$.

Growth in the Grower Period. During the grower period, failed-intake calves maintained similar ADG to successful-intake calves and weaned-by-age calves (Table 3), but failed-intake calves were unable to compensate for their lower $\mathrm{BW}$ at the beginning of this period, such that they weighed approximately $15 \mathrm{~kg}$ less at the end of the grower period than the weanedby-age calves $\left(t_{1,10}=2.0, P=0.07\right)$.

\section{Experiment 2}

Descriptive Results: Age and Duration of Weaning. Thirty-one calves $(67.4 \%)$ completed weaning before d 63 of age (early), and 12 calves (26.1\%) completed weaning on or after d 63 of age (late). The weaning age for early- and late-weaning calves averaged $54.4 \pm 5.3 \mathrm{~d}$ (range: 44 to $62 \mathrm{~d}$ ) and $71.3 \pm 7.0 \mathrm{~d}$ (range:

Table 2. Experiment 1: Least squares means $( \pm \mathrm{SE})$ of daily milk intake, starter intake, and number of rewarded and unrewarded visits to the milk feeder for Holstein calves weaned by age or weaned by intake based on individual starter intake

\begin{tabular}{|c|c|c|c|c|}
\hline \multirow[b]{2}{*}{ Response variable } & \multirow[b]{2}{*}{$\begin{array}{l}\text { Weaned } \\
\text { by age }\end{array}$} & \multicolumn{2}{|c|}{ Weaned by intake ${ }^{2}$} & \multirow[b]{2}{*}{$\mathrm{SE}$} \\
\hline & & $\begin{array}{l}\text { Failed } \\
\text { intake }\end{array}$ & $\begin{array}{l}\text { Successful } \\
\text { intake }\end{array}$ & \\
\hline \multicolumn{5}{|l|}{ Preweaning ( $\mathrm{d} 7$ to 30 ) } \\
\hline Milk DMI (kg/d) & 1.04 & 1.02 & 1.01 & 0.06 \\
\hline Starter DMI $(\mathrm{kg} / \mathrm{d})^{3}$ & $0.011^{\mathrm{x}}$ & $0.008^{\mathrm{a}, \mathrm{x}}$ & $0.018^{\mathrm{b}, \mathrm{y}}$ & 0.003 \\
\hline Rewarded visits (no./d) & 6.0 & 6.1 & 6.2 & 0.8 \\
\hline Unrewarded visits (no./d) & 0.6 & 0.3 & 0.6 & 0.3 \\
\hline \multicolumn{5}{|l|}{ Weaning (d 31 to 69 ) } \\
\hline Milk DMI $(\mathrm{kg} / \mathrm{d})$ & $0.59^{\mathrm{a}}$ & $0.57^{\mathrm{a}}$ & $0.23^{\mathrm{b}}$ & 0.04 \\
\hline Starter DMI $(\mathrm{kg} / \mathrm{d})$ & $0.49^{\mathrm{a}}$ & $0.29^{\mathrm{a}}$ & $1.2^{\mathrm{b}}$ & 0.1 \\
\hline Rewarded visits (no./d) & $6.7^{\mathrm{a}}$ & $5.7^{\mathrm{a}}$ & $3.0^{\mathrm{b}}$ & 0.6 \\
\hline Unrewarded visits (no./d) & $5.0^{\mathrm{a}}$ & $3.6^{\mathrm{a}}$ & $11.1^{\mathrm{b}}$ & 1.9 \\
\hline \multicolumn{5}{|l|}{ Postweaning (d 70 to 98 ) } \\
\hline Starter DMI (kg/d) & 3.3 & 3.2 & 3.6 & 0.3 \\
\hline Unrewarded visits (no./d) & $2.6^{\mathrm{a}}$ & $2.5^{\mathrm{ab}}$ & $1.8^{\mathrm{b}}$ & 0.4 \\
\hline \multicolumn{5}{|l|}{ Total calf rearing (d 7 to 98 ) } \\
\hline Milk DMI (kg) & $48.3^{\mathrm{a}}$ & $46.9^{\mathrm{a}}$ & $33.3^{\mathrm{b}}$ & 2.4 \\
\hline Starter DMI (kg) & $115.8^{\mathrm{a}}$ & $105.5^{\mathrm{a}}$ & $152.2^{\mathrm{b}}$ & 10.8 \\
\hline Rewarded visits (no.) & $406.4^{\mathrm{a}}$ & $371.2^{\mathrm{a}}$ & $267.0^{\mathrm{b}}$ & 40.9 \\
\hline Unrewarded visits (no.) & $285.1^{\mathrm{a}}$ & $220.1^{\mathrm{a}}$ & $498.4^{\mathrm{b}}$ & 79.2 \\
\hline \multicolumn{5}{|c|}{$\begin{array}{l}\mathrm{a}, \mathrm{b} ; \mathrm{x}, \mathrm{y} \\
\text { (x,y } 0.05<P \leq 0.1) \text { between weaned-by-age, failed-intake, and successful-intake calves. }\end{array}$} \\
\hline \multicolumn{5}{|c|}{$\begin{array}{l}{ }^{1} \text { Calves weaned by age were all weaned at d } 70(\mathrm{n}=16) \text {. Calves were offered } 12 \mathrm{~L} / \mathrm{d} \text { of milk until d } 30 \text {, and milk } \\
\text { allowance was gradually reduced between d } 30 \text { and } 35 \text { to reach a final allowance of } 6 \mathrm{~L} / \mathrm{d} \text {. This allowance was } \\
\text { fed until d } 63 \text {, when milk allowance was again gradually reduced until calves were completely weaned at d } 70 \text {. }\end{array}$} \\
\hline \multicolumn{5}{|c|}{$\begin{array}{l}{ }^{2} \text { Calves weaned by intake either successfully met the final intake target and were weaned before } \mathrm{d} 63 \text { of age } \\
(\mathrm{n}=10) \text { or failed to meet this target and were forced to wean over } 7 \mathrm{~d} \text { from d } 63 \text { to } 70 \text { of age }(\mathrm{n}=6) \text {. Calves } \\
\text { were offered } 12 \mathrm{~L} / \mathrm{d} \text { of milk until } \mathrm{d} 30 \text {, and then milk was reduced on d } 31 \text { to } 75 \% \text { of the calf's average milk } \\
\text { intake over the previous } 3 \mathrm{~d} \text {. A further } 25 \% \text { of milk was reduced for each calf when each starter intake target } \\
\text { was attained }(225,675 \text {, and } 1,300 \mathrm{~g} / \mathrm{d} \text { of calf starter, based on the average of the previous } 3 \mathrm{~d}) \text {. Weaning was } \\
\text { complete when the calf consumed } 1,300 \mathrm{~g} / \mathrm{d} \text { of calf starter. }\end{array}$} \\
\hline${ }^{3}$ Analysis was performed on & ed da & is anc & e reportec & \\
\hline
\end{tabular}


Table 3. Experiment 1: Least squares means $( \pm \mathrm{SE})$ of growth measures (body measurements, ADG, and final weight) for Holstein calves weaned by age or weaned by intake based on individual starter intake

\begin{tabular}{|c|c|c|c|c|}
\hline \multirow[b]{2}{*}{ Response variable } & \multirow[b]{2}{*}{$\begin{array}{l}\text { Weaned } \\
\text { by age }^{1}\end{array}$} & \multicolumn{2}{|c|}{ Weaned by intake ${ }^{2}$} & \multirow[b]{2}{*}{$\mathrm{SE}$} \\
\hline & & $\begin{array}{l}\text { Failed } \\
\text { intake }\end{array}$ & $\begin{array}{l}\text { Successful } \\
\text { intake }\end{array}$ & \\
\hline \multicolumn{5}{|l|}{ Preweaning (d 7 to 30$)$} \\
\hline Hip height $(\mathrm{HH}, \mathrm{cm} / \mathrm{d})$ & $0.36^{\mathrm{a}}$ & 0.43 & $0.49^{\mathrm{b}}$ & 0.05 \\
\hline Withers height (WH, cm/d) & $0.49^{\mathrm{x}}$ & $0.69^{\mathrm{y}}$ & $0.47^{\mathrm{x}}$ & 0.11 \\
\hline Body length $(\mathrm{BL}, \mathrm{cm} / \mathrm{d})$ & 0.22 & 0.41 & 0.27 & 0.15 \\
\hline Hip width $(\mathrm{HW}, \mathrm{cm} / \mathrm{d})$ & 0.08 & 0.06 & 0.04 & 0.07 \\
\hline Heart girth (HG, cm/d) & 0.44 & 0.25 & 0.39 & 0.11 \\
\hline Body barrel (BB, cm/d) & 0.82 & 0.56 & 0.65 & 0.14 \\
\hline $\mathrm{ADG}(\mathrm{kg} / \mathrm{d})$ & 0.95 & 0.86 & 0.90 & 0.07 \\
\hline \multicolumn{5}{|l|}{ Weaning (d 31 to 69 ) } \\
\hline $\mathrm{HH}(\mathrm{cm} / \mathrm{d})$ & $0.22^{\mathrm{a}}$ & $0.12^{\mathrm{b}}$ & $0.20^{\mathrm{a}}$ & 0.03 \\
\hline $\mathrm{WH}(\mathrm{cm} / \mathrm{d})$ & 0.21 & 0.14 & 0.22 & 0.06 \\
\hline $\mathrm{BL}(\mathrm{cm} / \mathrm{d})$ & 0.23 & 0.18 & 0.21 & 0.06 \\
\hline $\mathrm{HW}(\mathrm{cm} / \mathrm{d})$ & 0.03 & 0.02 & 0.02 & 0.03 \\
\hline $\mathrm{HG}(\mathrm{cm} / \mathrm{d})$ & $0.29^{\mathrm{a}}$ & $0.21^{\mathrm{b}, \mathrm{x}}$ & $0.28^{\mathrm{y}}$ & 0.04 \\
\hline $\mathrm{BB}(\mathrm{cm} / \mathrm{d})$ & $0.33^{\mathrm{a}}$ & $0.20^{\mathrm{a}}$ & $0.49^{\mathrm{b}}$ & 0.08 \\
\hline $\mathrm{ADG}(\mathrm{kg} / \mathrm{d})$ & $0.54^{\mathrm{x}}$ & $0.37^{\mathrm{a}, \mathrm{y}}$ & $0.66^{\mathrm{b}}$ & 0.1 \\
\hline \multicolumn{5}{|l|}{ Postweaning (d 70 to 98 ) } \\
\hline $\mathrm{HH}(\mathrm{cm} / \mathrm{d})$ & 0.25 & 0.28 & 0.25 & 0.03 \\
\hline $\mathrm{WH}(\mathrm{cm} / \mathrm{d})$ & 0.23 & 0.20 & 0.25 & 0.04 \\
\hline $\mathrm{BL}(\mathrm{cm} / \mathrm{d})$ & 0.27 & $0.20^{\mathrm{x}}$ & $0.30^{\mathrm{y}}$ & 0.04 \\
\hline $\mathrm{HW}(\mathrm{cm} / \mathrm{d})$ & 0.09 & 0.09 & 0.11 & 0.04 \\
\hline $\mathrm{HG}(\mathrm{cm} / \mathrm{d})$ & 0.43 & 0.42 & 0.44 & 0.03 \\
\hline $\mathrm{BB}(\mathrm{cm} / \mathrm{d})$ & $0.80^{\mathrm{a}}$ & $0.84^{\mathrm{a}}$ & $0.61^{\mathrm{b}}$ & 0.09 \\
\hline $\mathrm{ADG}(\mathrm{kg} / \mathrm{d})$ & $1.55^{\mathrm{x}}$ & $1.52^{\mathrm{xy}}$ & $1.42^{\mathrm{y}}$ & 0.09 \\
\hline \multicolumn{5}{|l|}{ Total calf rearing (d 7 to 98 ) } \\
\hline Initial HH $(\mathrm{cm})$ & $83.5^{\mathrm{a}}$ & 82.1 & $80.6^{\mathrm{b}}$ & 1.6 \\
\hline Final HH $(\mathrm{cm})$ & $105.2^{\mathrm{x}}$ & $102.6^{\mathrm{y}}$ & 104.8 & 1.5 \\
\hline Initial WH (cm) & 80.2 & 79.8 & 78.3 & 1.6 \\
\hline Final WH $(\mathrm{cm})$ & 101.5 & 99.2 & 101.0 & 1.5 \\
\hline Initial HW (cm) & 18.7 & 18.2 & 18.4 & 1.6 \\
\hline Final HW (cm) & $21.5^{\mathrm{x}}$ & $20.9^{\mathrm{a}}$ & $22.5^{\mathrm{b}, \mathrm{y}}$ & 0.7 \\
\hline Initial HG (cm) & 85.1 & 84.8 & 86.2 & 2.4 \\
\hline Final HG $(\mathrm{cm})$ & $117.0^{\mathrm{a}}$ & $112.2^{\mathrm{b}}$ & $117.1^{\mathrm{a}}$ & 1.7 \\
\hline Initial BL (cm) & 62.1 & 58.4 & 59.0 & 2.6 \\
\hline Final BL $(\mathrm{cm})$ & $82.7^{\mathrm{x}}$ & $79.7^{\mathrm{y}}$ & 82.5 & 1.8 \\
\hline Initial BB $(\mathrm{cm})$ & 85.8 & 91.3 & 85.9 & 5.2 \\
\hline Final BB (cm) & 137.7 & 133.8 & 137.2 & 2.7 \\
\hline Initial weight (kg) & 38.6 & 40.5 & 37.8 & 2.5 \\
\hline Final weight ${ }^{3}(\mathrm{~kg})$ & $134.2^{\mathrm{a}}$ & $122.8^{\mathrm{b}, \mathrm{x}}$ & $133.8^{\mathrm{y}}$ & 5.7 \\
\hline $\mathrm{ADG}(\mathrm{kg} / \mathrm{d})$ & 0.98 & 0.89 & 0.98 & 0.06 \\
\hline \multicolumn{5}{|l|}{ Grower (d 99 to 134 ) } \\
\hline Arrival weight ${ }^{4}(\mathrm{~kg})$ & $149.2^{\mathrm{a}}$ & $137.3^{\mathrm{b}, \mathrm{x}}$ & $148.7^{\mathrm{y}}$ & 5.9 \\
\hline Final weight $^{4}(\mathrm{~kg})$ & $195.2^{\mathrm{x}}$ & $180.1^{\mathrm{y}}$ & 188.2 & 7.2 \\
\hline $\mathrm{ADG}(\mathrm{kg} / \mathrm{d})$ & 1.48 & 1.48 & 1.41 & 0.1 \\
\hline
\end{tabular}

${ }_{\mathrm{a}, \mathrm{b} ; \mathrm{x}, \mathrm{y}}$ Means with different superscripts within a row indicate a significant difference $\left({ }^{\mathrm{a}, \mathrm{b}} P \leq 0.05\right)$ or a tendency $\left({ }^{\mathrm{x}, \mathrm{y}} 0.05<P \leq 0.1\right)$ between weaned-by-age, failed-intake, and successful-intake calves.

${ }^{1}$ Calves weaned by age were all weaned at d $70(\mathrm{n}=16)$. Calves were offered $12 \mathrm{~L} / \mathrm{d}$ of milk until d 30, and milk allowance was gradually reduced between d 30 and 35 to reach a final allowance of $6 \mathrm{~L} / \mathrm{d}$. This allowance was fed until d 63, when milk allowance was again gradually reduced until calves were completely weaned at d 70 . ${ }^{2}$ Calves weaned by intake either successfully met the final intake target and were weaned before d 63 of age $(\mathrm{n}=10)$ or failed to meet this target and were forced to wean over $7 \mathrm{~d}$ from $\mathrm{d} 63$ to 70 of age $(\mathrm{n}=6)$. Calves were offered $12 \mathrm{~L} / \mathrm{d}$ of milk until d 30, and then milk was reduced on d 31 to $75 \%$ of the calf's average milk intake over the previous $3 \mathrm{~d}$. A further $25 \%$ of milk was reduced for each calf when each starter intake target was attained $(225,675$, and $1,300 \mathrm{~g} / \mathrm{d}$ of calf starter, based on the average of the previous $3 \mathrm{~d})$. Weaning was complete when the calf consumed $1,300 \mathrm{~g} / \mathrm{d}$ of calf starter.

${ }^{3}$ Final weight at the end of the calf-rearing period was measured at wk 11 (d 98) of age.

${ }^{4}$ Initial weight at the start of the grower period was measured when the entire group arrived at the grower facility at, nominally, wk 15 (mean \pm SD; $109.0 \pm 10.6 \mathrm{~d}$ of age). Final weight at the end of the grower period was measured at, nominally, wk 19 (mean $\pm \mathrm{SD} ; 134.4 \pm 11.7 \mathrm{~d}$ of age). 

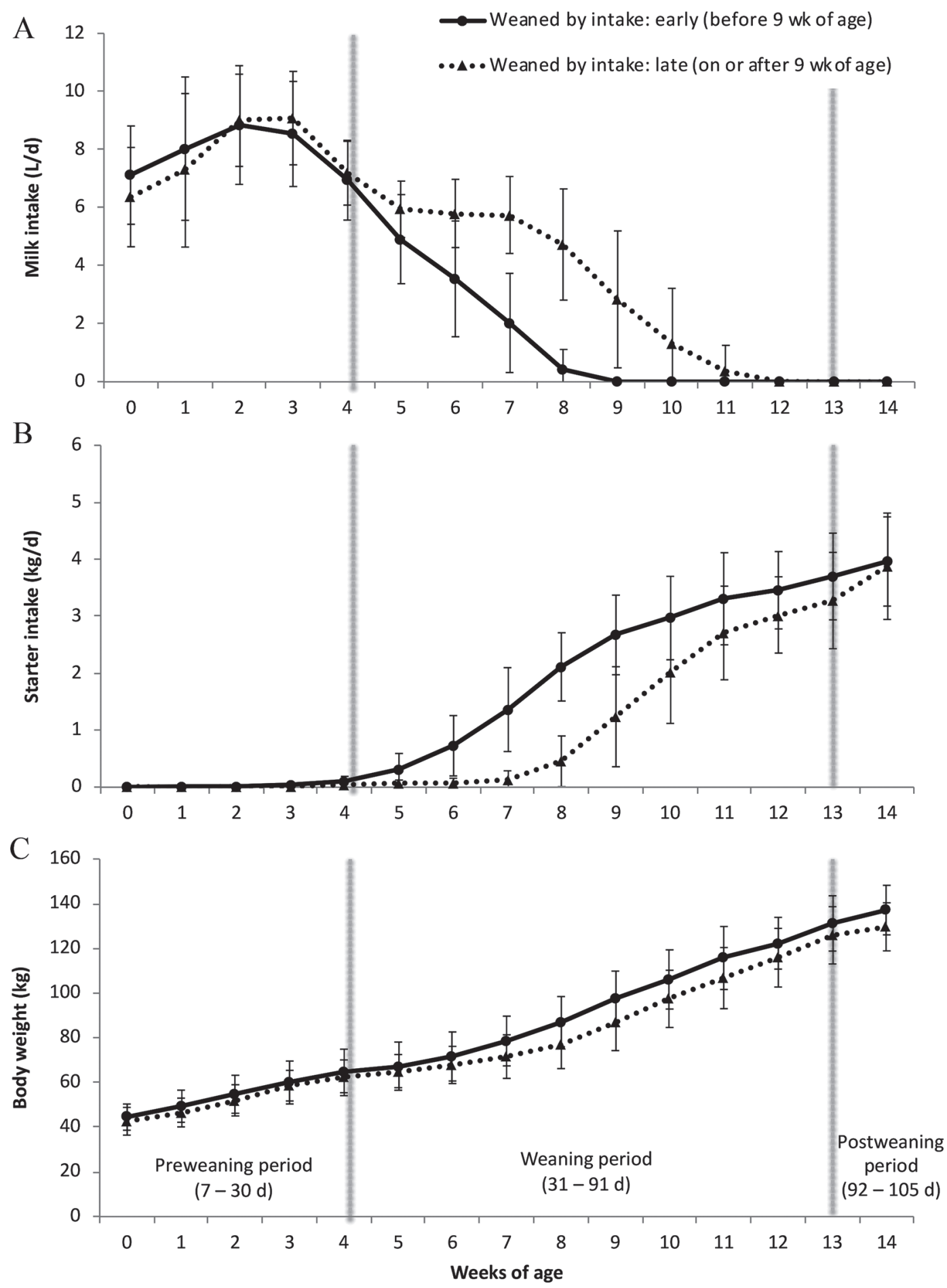

Figure 2. Experiment 2: arithmetic means $( \pm \mathrm{SD})$ for descriptive purposes of $(\mathrm{A})$ milk intake, $(\mathrm{B})$ starter intake, and (C) BW for Holstein calves aged 0 to $14 \mathrm{wk}$. Values are shown separately for calves that weaned by intake early (completed weaning before $9 \mathrm{wk} ; \mathrm{n}=31$ ) and late (completed weaning on or after $9 \mathrm{wk} ; \mathrm{n}=12$ ). All calves received $12 \mathrm{~L} / \mathrm{d}$ until wk 4 . Milk allowance was reduced by $25 \%$ of each individual's allowance on wk 4 , and then a further $25 \%$ when each calf reached each target of grain $(225,675$, and $1,300 \mathrm{~g} / \mathrm{d})$ until complete weaning at 1,300 $\mathrm{g} / \mathrm{d}$ of calf starter. Calves were permitted up to $12 \mathrm{wk}$ to complete weaning; calves that failed to wean by this time are not shown. 
Table 4. Experiment 2: Least squares means $( \pm \mathrm{SE})$ of daily milk intake, starter intake, and number of rewarded and unrewarded visits to the milk feeder for 43 Holstein calves successfully weaned by intake based on individual starter intake

\begin{tabular}{|c|c|c|c|}
\hline \multirow[b]{2}{*}{ Response variable } & \multicolumn{2}{|c|}{ Weaned by intake ${ }^{1}$} & \multirow[b]{2}{*}{$\mathrm{SE}$} \\
\hline & Early & Late & \\
\hline \multicolumn{4}{|l|}{ Preweaning (d 1 to 30$)$} \\
\hline Milk DMI $(\mathrm{kg} / \mathrm{d})$ & 1.03 & 0.98 & 0.06 \\
\hline Starter DMI $(\mathrm{kg} / \mathrm{d})^{2}$ & $0.014^{\mathrm{a}}$ & $0.0038^{\mathrm{b}}$ & 0.003 \\
\hline Rewarded visits (no./d) & 6.9 & 6.6 & 0.6 \\
\hline Unrewarded visits (no./d) & 0.8 & 0.4 & 0.4 \\
\hline \multicolumn{4}{|l|}{ Weaning (d 31 to 91 ) } \\
\hline Milk DMI $(\mathrm{kg} / \mathrm{d})$ & $0.20^{\mathrm{a}}$ & $0.43^{\mathrm{b}}$ & 0.03 \\
\hline Starter DMI $(\mathrm{kg} / \mathrm{d})$ & $1.8^{\mathrm{a}}$ & $0.99^{\mathrm{b}}$ & 0.1 \\
\hline Rewarded visits (no./d) & $2.6^{\mathrm{a}}$ & $5.1^{\mathrm{b}}$ & 0.3 \\
\hline Unrewarded visits (no./d) & 7.0 & 7.6 & 1.0 \\
\hline \multicolumn{4}{|l|}{ Postweaning (d 92 to 105 ) } \\
\hline Starter DMI $(\mathrm{kg} / \mathrm{d})$ & 3.3 & 3.0 & 0.2 \\
\hline Unrewarded visits (no./d) & 2.6 & 2.4 & 0.3 \\
\hline \multicolumn{4}{|l|}{ Total calf rearing (d 1 to 105 ) } \\
\hline Milk DMI (kg) & $43.3^{\mathrm{a}}$ & $55.5^{\mathrm{b}}$ & 3.2 \\
\hline Starter DMI (kg) & $156.7^{\mathrm{a}}$ & $105.4^{\mathrm{b}}$ & 9.8 \\
\hline Rewarded visits (no.) & $361.3^{\mathrm{a}}$ & $516.0^{\mathrm{b}}$ & 29.0 \\
\hline Unrewarded visits (no.) & 478.5 & 515.0 & 61.6 \\
\hline
\end{tabular}

${ }^{a, b}$ Means with different superscripts within a row indicate a significant difference $(P \leq 0.05)$.

${ }^{1}$ Calves were offered $12 \mathrm{~L} / \mathrm{d}$ of milk until d 30, and then milk was reduced on d 31 to $75 \%$ of the calf's average milk intake over the previous $3 \mathrm{~d}$. A further $25 \%$ of milk was reduced for each calf when each starter intake target was attained $(225,675$, and $1,300 \mathrm{~g} / \mathrm{d}$ of calf starter, based on the average of the previous $3 \mathrm{~d})$. Weaning was complete when the calf consumed $1,300 \mathrm{~g} / \mathrm{d}$ of calf starter. These calves were retrospectively classified as weaned early (before $63 \mathrm{~d}$ of age, $\mathrm{n}=31$ ) or late (on or after $63 \mathrm{~d}$ of age, $\mathrm{n}=12$ ).

${ }^{2}$ Analysis was performed on square-root-transformed data; raw means and SE are reported.

63 to $84 \mathrm{~d}$ ), and the duration of weaning (from when the first starter intake target of $225 \mathrm{~g} / \mathrm{d}$ was reached to complete weaning at $1,300 \mathrm{~g} / \mathrm{d}$ ) averaged $12.6 \pm 4.1 \mathrm{~d}$ (range: 6 to $22 \mathrm{~d}$ ) and $10.2 \pm 5.5 \mathrm{~d}$ (range: 6 to $24 \mathrm{~d}$ ), respectively. Milk allowance at step-down on d 31 for early- and late-weaning calves averaged $6.2 \pm 1.2$ and $6.5 \pm 0.9 \mathrm{~L} / \mathrm{d}$, respectively. Weekly milk intake, starter intake, and BW for early- and late-weaning calves are illustrated for descriptive purposes in Figure 2.

Milk Intake. We detected large variability in average milk intake in the preweaning period, ranging from 5.6 to $11.2 \mathrm{~L} / \mathrm{d}$ (mean $8.2 \mathrm{~L} / \mathrm{d}$ ) for early-weaning calves and from 5.7 to $9.3 \mathrm{~L} / \mathrm{d}$ (mean $8.1 \mathrm{~L} / \mathrm{d}$ ) for late-weaning calves (Supplemental Figure S1; https://doi.org/10 $.3168 /$ jds.2018-15830). Milk intake declined at around wk 5 for early-weaning calves and wk 8 for late-weaning calves. Total cumulative milk DMI for early-weaning calves was about $12 \mathrm{~kg}$ less than that for late-weaning calves $\left(F_{1,33}=13.1, P<0.01\right.$; Table 4$)$; this difference was most pronounced during the weaning period $\left(F_{1,33}\right.$ $=39.0, P<0.001)$. There was no difference in preweaning milk intake between the 2 weaning outcome groups.

Rewarded and Unrewarded Visits. As expected, early-weaning calves had about half the number of rewarded visits to the milk feeder during weaning (about
2.5 visits $/ \mathrm{d})$ compared with late-weaning calves $\left(F_{1,33}\right.$ $=46.0, P<0.001$; Table 4$)$, but these groups did not differ preweaning. Unrewarded visits to the milk feeder were similar for early- and late-weaning calves across all calf-rearing periods.

Starter Intake. Starter intake began to increase at about wk 4 for early-weaning calves (soon after the initial 25\% reduction in milk allowance) but at about wk 8 for late-weaning calves. Total cumulative starter intake during calf rearing was higher for early-weaning calves than for late-weaning calves $\left(F_{1,33}=22.5, P<\right.$ 0.001 ), with a difference of approximately $50 \mathrm{~kg}$; this difference was mainly driven by the weaning period $\left(F_{1,33}=31.6, P<0.001\right)$, but early-weaning calves also consumed more starter before weaning $\left(F_{1.33}=7.1, P\right.$ $=0.01$; Table 4$)$. Starter DMI did not differ between weaning outcomes after weaning.

Growth During the Total Calf-Rearing Period. Body weight was similar between early- and late-weaning calves until around wk 8, after which early-weaning calves had greater BW for the remainder of the calfrearing period. Total ADG for the calf-rearing period was greater for early- versus late-weaning calves $\left(F_{1,33}\right.$ $=4.3, P=0.05)$, driven by a difference of $150 \mathrm{~g} / \mathrm{d}$ ADG in the weaning period $\left(F_{1,33}=18.0, P<0.001\right.$; 
Table 5. Experiment 2: Least squares means $( \pm \mathrm{SE})$ of growth measures (body measurements, ADG, and final weight) for 43 Holstein calves successfully weaned by intake based on individual starter intake

\begin{tabular}{|c|c|c|c|}
\hline \multirow[b]{2}{*}{ Response variable } & \multicolumn{2}{|c|}{ Weaned by intake ${ }^{1}$} & \multirow[b]{2}{*}{$\mathrm{SE}$} \\
\hline & Early & Late & \\
\hline \multicolumn{4}{|l|}{ Preweaning (d 1 to 30$)$} \\
\hline Hip height (HH, cm/d) & 0.25 & 0.20 & 0.04 \\
\hline Withers height $(\mathrm{WH}, \mathrm{cm} / \mathrm{d})$ & $0.28^{\mathrm{a}}$ & $0.19^{\mathrm{b}}$ & 0.04 \\
\hline Body length $(\mathrm{BL}, \mathrm{cm} / \mathrm{d})$ & 0.22 & 0.25 & 0.05 \\
\hline Hip width $(\mathrm{HW}, \mathrm{cm} / \mathrm{d})$ & 0.10 & 0.11 & 0.02 \\
\hline Heart girth $(\mathrm{HG}, \mathrm{cm} / \mathrm{d})$ & 0.43 & 0.45 & 0.03 \\
\hline Body barrel (BB, cm/d) & 0.67 & 0.65 & 0.08 \\
\hline $\mathrm{ADG}(\mathrm{kg} / \mathrm{d})$ & 0.75 & 0.75 & 0.07 \\
\hline \multicolumn{4}{|l|}{ Weaning (d 31 to 91$)$} \\
\hline $\mathrm{HH}(\mathrm{cm} / \mathrm{d})$ & 0.23 & 0.25 & 0.02 \\
\hline $\mathrm{WH}(\mathrm{cm} / \mathrm{d})$ & $0.23^{\mathrm{a}}$ & $0.27^{\mathrm{b}}$ & 0.01 \\
\hline $\mathrm{BL}(\mathrm{cm} / \mathrm{d})$ & 0.26 & 0.23 & 0.03 \\
\hline $\mathrm{HW}(\mathrm{cm} / \mathrm{d})$ & $0.10^{\mathrm{a}}$ & $0.06^{\mathrm{b}}$ & 0.008 \\
\hline $\mathrm{HG}(\mathrm{cm} / \mathrm{d})$ & $0.38^{\mathrm{a}}$ & $0.33^{\mathrm{b}}$ & 0.02 \\
\hline $\mathrm{BB}(\mathrm{cm} / \mathrm{d})$ & 0.60 & 0.54 & 0.04 \\
\hline ADG $(\mathrm{kg} / \mathrm{d})$ & $1.08^{\mathrm{a}}$ & $0.94^{\mathrm{b}}$ & 0.03 \\
\hline \multicolumn{4}{|l|}{ Postweaning (d 92 to 105 ) } \\
\hline $\mathrm{HH}(\mathrm{cm} / \mathrm{d})$ & 0.31 & 0.23 & 0.07 \\
\hline $\mathrm{WH}(\mathrm{cm} / \mathrm{d})$ & 0.31 & 0.20 & 0.07 \\
\hline $\mathrm{BL}(\mathrm{cm} / \mathrm{d})$ & 0.32 & 0.20 & 0.08 \\
\hline $\mathrm{HW}(\mathrm{cm} / \mathrm{d})$ & $0.03^{\mathrm{a}}$ & $0.14^{\mathrm{b}}$ & 0.03 \\
\hline $\mathrm{HG}(\mathrm{cm} / \mathrm{d})$ & $0.34^{\mathrm{a}}$ & $0.52^{\mathrm{b}}$ & 0.05 \\
\hline $\mathrm{BB}(\mathrm{cm} / \mathrm{d})$ & 0.48 & 0.60 & 0.11 \\
\hline $\mathrm{ADG}(\mathrm{kg} / \mathrm{d})$ & 1.35 & 1.41 & 0.09 \\
\hline \multicolumn{4}{|l|}{ Total calf rearing (d 1 to 105$)$} \\
\hline Initial $\mathrm{HH}(\mathrm{cm})$ & 84.5 & 84.6 & 0.71 \\
\hline Final $\mathrm{HH}(\mathrm{cm})$ & 109.5 & 108.8 & 1.0 \\
\hline Initial WH $(\mathrm{cm})$ & 81.1 & 81.0 & 0.69 \\
\hline Final WH $(\mathrm{cm})$ & 106.6 & 106.2 & 1.0 \\
\hline Initial BL $(\mathrm{cm})$ & 59.5 & 59.8 & 1.0 \\
\hline Final BL $(\mathrm{cm})$ & $86.2^{\mathrm{a}}$ & $82.8^{\mathrm{b}}$ & 1.2 \\
\hline Initial HW (cm) & 13.4 & 13.5 & 0.23 \\
\hline Final HW (cm) & 22.4 & 21.8 & 0.52 \\
\hline Initial HG $(\mathrm{cm})$ & 82.9 & 82.4 & 0.57 \\
\hline Final HG (cm) & 122.9 & 122.7 & 1.2 \\
\hline Initial BB $(\mathrm{cm})$ & 85.4 & 85.4 & 1.6 \\
\hline Final BB $(\mathrm{cm})$ & $145.7^{\mathrm{a}}$ & $140.3^{\mathrm{b}}$ & 2.2 \\
\hline Initial weight $(\mathrm{kg})$ & 40.4 & 39.3 & 1.7 \\
\hline Final weight ${ }^{2}(\mathrm{~kg})$ & 148.2 & 142.9 & 3.0 \\
\hline $\mathrm{ADG}(\mathrm{kg} / \mathrm{d})$ & $1.02^{\mathrm{a}}$ & $0.96^{\mathrm{b}}$ & 0.03 \\
\hline \multicolumn{4}{|l|}{ Grower (d 106 to 145$)$} \\
\hline Arrival weight $^{3}(\mathrm{~kg})$ & $163.1^{\mathrm{x}}$ & $155.5^{\mathrm{y}}$ & 3.8 \\
\hline Final weight $^{3}(\mathrm{~kg})$ & $203.2^{\mathrm{a}}$ & $192.6^{\mathrm{b}}$ & 4.2 \\
\hline $\mathrm{ADG}(\mathrm{kg} / \mathrm{d})$ & 1.44 & 1.35 & 0.07 \\
\hline
\end{tabular}

$\overline{\mathrm{a}, \mathrm{b} ; \mathrm{x}, \mathrm{y}}$ Means with different superscripts within a row indicate a significant difference $\left({ }^{\mathrm{a}, \mathrm{b}} P \leq 0.05\right)$ or a tendency $\left({ }^{\mathrm{x}, \mathrm{y}} 0.05<P \leq 0.1\right)$ between calves that weaned early or late.

${ }^{1}$ Calves were offered $12 \mathrm{~L} / \mathrm{d}$ of milk until d 30, and then milk was reduced on d 31 to $75 \%$ of the calf's average milk intake over the previous $3 \mathrm{~d}$. A further $25 \%$ of milk was reduced for each calf when each starter intake target was attained $(225,675$, and $1,300 \mathrm{~g} / \mathrm{d}$ of calf starter, based on the average of the previous $3 \mathrm{~d})$. Weaning was complete when the calf consumed $1,300 \mathrm{~g} / \mathrm{d}$ of calf starter. These calves were retrospectively classified as weaned early (before $63 \mathrm{~d}$ of age, $\mathrm{n}=31$ ) or late (on or after $63 \mathrm{~d}$ of age, $\mathrm{n}=12$ ).

${ }^{2}$ Final weight at the end of the calf-rearing period was measured at wk 15 (d 105) of age. Of 43 calves, 14 were too heavy at d 105 to be measured using the scale in the calf-rearing facility; therefore, an estimate of final weight was calculated based on the previous obtained weight and the weight obtained upon arrival at the grower facility.

${ }^{3}$ Initial weight at the start of the grower period was measured when the entire group arrived at the grower facility at, nominally, wk 16 (mean $\pm \mathrm{SD} ; 117.1 \pm 8.6 \mathrm{~d}$ of age). Final weight at the end of the grower period was measured at, nominally, wk 20 (mean $\pm \mathrm{SD} ; 144.6 \pm 8.0 \mathrm{~d}$ ) of age. 
Table 5). Final BW at the end of the calf-rearing period (d 105 of age) was similar between weaning outcomes $\left(F_{1,33}=2.4, P=0.14\right)$.

Daily body measurement growth differed between weaning outcomes for the preweaning, weaning, and postweaning periods. Calves that weaned late (versus early) had reduced withers height growth preweaning $\left(F_{1,33}=2.7, P<0.01\right)$, but greater withers height growth during weaning $\left(F_{1,33}=2.5, P=0.02\right)$. These late-weaning calves also had reduced hip width and heart girth growth during weaning $\left(F_{1,33}>4.3, P<\right.$ $0.05)$ but compensated postweaning with increased growth for these measures $\left(F_{1.33}>3.1, P<0.01\right)$. Final measures of body length $\left(F_{1,33}=2.9, P<0.01\right)$ and body barrel $\left(F_{1,33}=2.4, P=0.02\right)$ were lower for lateweaning calves than for early-weaning calves at the end of the calf-rearing period.

Growth in the Grower Period. During the grower period, late-weaning calves had similar ADG to earlyweaning calves (Table 5); however, at the end of the grower period (d 145 of age), late-weaning calves weighed about $10 \mathrm{~kg}$ less than early-weaning calves $\left(t_{1,32}=2.2, P=0.04\right)$.

\section{DISCUSSION}

This study is the first to compare a gradual (stepdown technique) weaning method based on age and weaning based on starter intake. Calves in both experiments were provided an elevated plane of nutrition coupled with gradual weaning. In experiment 1 , not all calves enrolled in the weaned-by-intake treatment were able to meet the final starter intake target for weaning. Calves that reached the final target (i.e., successfulintake calves) consumed less milk and more starter than calves weaned by age. Importantly, these calves achieved similar weight gains and structural growth despite consuming less milk and weaning earlier than calves weaned by age. Others have reported similar findings for intakes and weight gains between calves weaned based on intake and calves weaned at $12 \mathrm{wk}$ (Roth et al., 2009) or 13 wk of age (de Passillé and Rushen, 2016).

Not all calves in experiment 1 were able to wean by intake successfully before 9 wk of age; therefore, in experiment 2, we allowed calves an extended period (up to $12 \mathrm{wk}$ ) to complete weaning based on feed intake. In experiment 2, we again found that calves varied in when they met this target. The majority of calves weaned before 9 wk of age; these early-weaning calves consumed less milk and more starter and had greater overall ADG and some improvements in structural growth (body length and body barrel) during the calfrearing period compared with calves that weaned late.
These results do not necessarily imply that weaning early is better than weaning later; it is important to note that the benefits of early weaning in this study applied only to calves that progressed through weaning at their own pace and thus had early intake of starter that prepared them for this transition. Weaning calves from high milk allowances too early can result in reduced growth (Sweeney et al., 2010), which is likely a consequence of weaning calves that are not yet accustomed to eating solid feeds.

Dennis et al. (2018a,b) found that calves fed high amounts of milk had similar weight gain and structural growth at d 112 of age when weaned at 6 wk versus $8 \mathrm{wk}$, but in those studies calves were weaned over a 7-d period and with once-daily feeding. That weaning procedure is more abrupt and aggressive than the one we applied and may not have provided sufficient time for the later-weaned calves to compensate for the loss of milk with increased starter intakes and thus maintain their preweaning weight gain advantage. In contrast, several studies have found improved weight gains in calves weaned at later ages from high milk allowances (Eckert et al., 2015; Meale et al., 2015; Mirzaei et al., 2018).

A common feeding strategy for dairy calves has been to provide a restrictive milk allowance to encourage early starter intake (Hill et al., 2010; see review by Kertz and Loften, 2013). However, restricting milk allowance results in poor growth before weaning compared with feeding higher amounts of milk from an early age (Geiger et al., 2016; Frieten et al., 2017; reviewed by Khan et al., 2011). Feeding greater milk allowances is one way to promote enhanced growth, but this approach has been criticized for depressing starter intake before weaning (Borderas et al., 2009; Raeth-Knight et al., 2009) and increasing the growth check at weaning when weaning abruptly (Sweeney et al., 2010; de Passillé et al., 2011; Eckert et al., 2015). When feeding high amounts of milk, step-down weaning methods are an effective way to encourage starter intakes while maintaining high growth (Khan et al., 2007a). Studies have also shown improved metabolic (Steele et al., 2017) and physical ruminal development (Khan et al., 2007b) in calves fed high amounts of milk on a step-down weaning program. The results of the current study suggest that combining a milk step-down at $30 \mathrm{~d}$ of age with weaning by intake offers benefits similar to that of a regular step-down weaning program (such as reduced milk intake with high postweaning weight gains), with the advantages that (1) weaning is individualized such that calves progress through weaning as they become familiar with starter, and (2) calves consume less milk and are weaned at a younger age. In this study, we were unable to accurately record intake of hay and did not 
include measures of rumen morphology or physiology; we encourage future work to investigate differences in forage intake and ruminal development before, during, and after weaning for individuals on this type of weaning strategy compared with conventional weaning by age. In addition, we noted that calves had variable milk intakes during the preweaning period, averaging 8 to $9 \mathrm{~L} / \mathrm{d}$ despite an allowance of up to $12 \mathrm{~L} / \mathrm{d}$; variability in milk intake for calves fed high amounts of milk replacer has previously been observed (e.g., Dennis et al., 2018a). In our previous study, calves that were fed restricted milk allowances $(6 \mathrm{~L} / \mathrm{d})$ did not always consume their full allotment (Rosenberger et al., 2017). We suggest that variability in milk intake is related to individual differences in how calves interact with the automated feeder.

The majority of calves in both experiment 1 and experiment 2 weaned before 9 wk of age, averaging 52 and $54 \mathrm{~d}$, respectively. Other studies that weaned calves based on starter intake have reported much later weaning ages (approximately 11 wk of age: Roth et al., 2009; de Passillé and Rushen, 2016). Weaning duration was also relatively short for calves in both experiments; after meeting the first starter intake target, calves were fully weaned within $11 \mathrm{~d}$ on average, regardless of whether they weaned before or after 9 wk of age. de Passillé and Rushen (2016) reported a weaning duration of $21 \mathrm{~d}$ for calves weaned in the same facility using similar starter intake targets. The differences in average weaning age and duration between these studies are likely related to the addition of the initial step-down of milk at $d$ 30 in the current study. All calves in the current study showed minimal starter intake before this initial milk step-down, after which starter intake increased rapidly. This result is consistent with previous work on stepdown weaning (Khan et al., 2007a; Eckert et al., 2015) and may be especially useful when calves are fed high allowances of milk (Rosenberger et al., 2017).

We observed large individual differences in the age that individuals completed weaning based on intake, ranging from 44 to $62 \mathrm{~d}$ in experiment 1 and from 40 to $84 \mathrm{~d}$ in experiment 2. This variability has been reported in other studies feeding high (de Passillé and Rushen, 2012; Neave et al., 2018) and low amounts of milk (Roth et al., 2009) and has been associated with personality differences in how calves interact with their feeding environment during weaning (Neave et al., 2018). Interestingly, calves that successfully weaned based on intake before 9 wk of age (successful-intake and early-weaning calves in experiments 1 and 2 , respectively) had greater starter intakes in the first $30 \mathrm{~d}$ of life (i.e., even before the initial milk reduction) compared with those that weaned by age or those that did not wean by intake before $9 \mathrm{wk}$ of age (failed-intake and late-weaning calves in experiments 1 and 2, respectively). These findings indicate that calves differ in their interest in starter and that this affects their ability to wean by intake. These differences may be related to the exploratory nature of the individual, where some calves are more likely to find food sources in their environment, or may be related to food neophobia, where the fear of novel foods (Chapple and Lynch, 1986; Costa et al., 2014) may limit the ability of calves to begin eating starter. Differences in food motivation may also play a role in the early and continued consumption of starter, but this has yet to be investigated. Although these individual characteristics may identify calves that are likely to transition quickly to starter, they are not yet easily and quickly measurable on commercial farms. However, we also found that calves that completed weaning earlier consumed more starter in the first $30 \mathrm{~d}$ of age, especially during wk 4, suggesting that starter intake in the first few weeks of life may be an indicator that calves are be able to be weaned off milk relatively quickly. Future research should investigate the use of this and other measures to identify calves that perform best on particular weaning programs, helping to support the use of individualized feeding programs.

Not all calves in experiment 1 were able to meet the weaning target of $1,300 \mathrm{~g} / \mathrm{d}$ of starter intake; these failed-intake calves followed a nearly identical weaning plan to those that were weaned by age and thus had similar overall consumption of milk and starter. However, these failed-intake calves had lower hip height, heart girth, and body barrel growth during weaning, which translated to lower hip height, hip width, heart girth, and body length at the end of the calf-rearing period (d 98 of age). Failed-intake calves also weighed about 12 $\mathrm{kg}$ less than weaned-by-age or successful-intake calves at the end of calf-rearing period, and were not able to make up for this weight difference in the grower period (averaging $180 \mathrm{~kg}$ vs. 195 and $188 \mathrm{~kg}$, respectively, at the end of the grower period). These findings suggest that these failed-intake calves may respond poorly to nutritional stressors (such as weaning), given that they consumed similar starter DMI but failed to achieve the structural growth of those calves on a similar weaning plan. These calves may benefit from a longer period of access to high milk rations. This result motivated the design for experiment 2, in which we provided an extended period to allow for weaning by intake.

In experiment 2, when calves were given up to $12 \mathrm{wk}$ to complete weaning, only 3 of 46 calves failed to meet the final target. This result indicates that even when allowed considerable flexibility, a small number of calves are likely to avoid starter before weaning, and thus are likely to have difficulties during weaning. There were too few of these "failed" calves to compare statisti- 
cally with the other groups, but we encourage future research to investigate which characteristics identify these at-risk individuals and determine what weaning plan works best for these calves. Calves that fail to wean early due to limited starter intake may benefit from techniques that facilitate consumption of starter from an early age, such as increasing palatability using a flavored additive (Morrill and Dayton, 1978; Montoro et al., 2011) or providing social models (de Paula Vieira et al., 2012).

The long-term performance of these calves that failed to wean early is also of interest. Only a few studies have followed calves beyond the first few weeks after weaning (up to 16 wk of age: Dennis et al., 2018a,b), which limits our understanding of the implications of different weaning programs and outcomes on future growth of heifers. Although our study was not powered to have these later weights as a primary outcome measure, we did find evidence that calves that failed to wean before 9 wk (failed intake, experiment 1) and calves that weaned after 9 wk (late weaning, experiment 2) were unable to compensate for their reduced weight during the grower period. Reduced weight or ADG during the prepubertal period and BW at calving have been associated with reduced mammary development and first-lactation milk yield (Zanton and Heinrichs, 2005); we encourage future work using studies specifically designed to examine the longer-term developmental consequences of different weaning trajectories.

Successful-intake calves in experiment 1 had more unrewarded visits to the milk feeder during the weaning period than failed-intake calves and weaned-by-age calves. This number of unrewarded visits (around 11 visits/d during weaning) was comparable to that reported by de Passillé and Rushen (2016) using the same facility and similar starter intake targets without an initial step-down milk reduction. High numbers of unrewarded visits to the milk feeder can indicate hunger in dairy calves (Jensen, 2006; de Paula Vieira et al., 2008), so the results of experiment 1 are consistent with the idea that successful-intake calves may have been more hungry. Indeed, it is possible that hunger for both milk and starter motivated these calves to reach the solid intake targets quickly, which led to the reduced milk allowance. In addition, previous work has shown more unrewarded visits to the milk feeder when calves are weaned at earlier ages (de Passillé et al., 2011); in the current study, the successful-intake calves weaned earlier than the weaned-by-age and failed-intake calves. However, in experiment 2, calves that weaned late had similar numbers of unrewarded visits to those calves that weaned early (before $9 \mathrm{wk}$ ), suggesting that the increased number of unrewarded visits by successful- intake calves in experiment 1 was not due to early weaning.

Another reason for the increase in unrewarded visits may have been the method of reducing milk after meeting the starter intake target (i.e., immediate reduction of $25 \%$ in the calf's milk allowance); from this perspective, the successful-intake calves experienced an abrupt reduction in milk at 3 separate time points. These milk reductions occurred, on average, over the course of 12 $\mathrm{d}$, with some calves weaning within just $1 \mathrm{wk}$. Abrupt weaning, or weaning over a short period, is known to result in a higher number of unrewarded visits to the milk feeder (Nielsen et al., 2008). This increase is typically a response to loss of energy intake during abrupt weaning, where calves are unable to compensate for reduced milk with increased starter. However, for calves weaned by intake, milk removal only occurred once sufficient starter was consumed, which minimized energy intake losses at milk removal; de Passillé and Rushen (2012) suggested that the increase in unrewarded visits for these calves is more likely a response to reduced milk intake than reduced energy intake. Future research should investigate ways to gradually reduce milk following starter intake targets that will reduce unrewarded visits to the milk feeder.

Weaning calves based on how much starter they are consuming is not new (e.g., Greenwood et al., 1997), but advances in computer-controlled feeding systems for calves have made gradual weaning less labor intensive and more precise (Kung et al., 1997; Hepola, 2003). Given the large individual differences in how quickly calves make the transition from milk to starter, there is a considerable opportunity to use automated feeders to wean calves individually. In doing so, milk can be allocated at the individual level; for instance, away from calves that transition quickly to starter and toward calves that need more time before weaning.

\section{CONCLUSIONS}

Automatic weaning based on individual starter intake, following a step-down in milk at $30 \mathrm{~d}$ of age, has the advantage of reducing weaning age and milk consumption while maintaining similar postweaning weights compared with calves weaned at a fixed age. Calves vary in when they reach the intake targets for weaning; allowing calves the opportunity to meet these targets over 12 wk resulted in fewer failures than when targets had to be met within the first 9 wk of age. These results illustrate the opportunities provided by individualized weaning programs, including the ability to better allocate milk to those calves less able to transition to starter at an early age. 


\section{ACKNOWLEDGMENTS}

We thank the staff and students of the UBC Dairy Education and Research Centre (Agassiz BC, Canada), especially Stephanie Boeve for help with the experiment and data collection. General funding for UBC's Animal Welfare Program comes from an NSERC Industrial Research Chair with industry contributions from the Dairy Farmers of Canada (Ottawa, ON, Canada), British Columbia Dairy Association (Burnaby, BC, Canada), Westgen Endowment Fund (Milner, BC, Canada), Intervet Canada Corporation (Kirkland, QC, Canada), Novus International Inc. (Oakville, ON, Canada), Zoetis (Kirkland, QC, Canada), BC Cattle Industry Development Fund (Kamloops, BC, Canada), Alberta Milk (Edmonton, AB, Canada), Valacta (St. Anne-de-Bellevue, QC, Canada), and CanWest DHI (Guelph, ON, Canada).

\section{REFERENCES}

AOAC International. 2000. Official Methods of Analysis. Vol. 1. 17th ed. AOAC Int., Arlington, VA.

Benetton, J. B., H.W. Neave, J.H.C. Costa, M.A.G. von Keyserlingk, and D.M. Weary. 2019. Benetton et al., 2019 (Journal of Dairy Science) - SAS Codes and Data Sets, Mendeley Data, v1. https:// doi.org/10.17632/cghv2nrty6.1.

Borderas, T. F., A. M. B. de Passillé, and J. Rushen. 2009. Feeding behavior of calves fed small or large amounts of milk. J. Dairy Sci. 92:2843-2852. https://doi.org/10.3168/jds.2008-1886.

Bovine Alliance on Management and Nutrition. 2017. A Guide to Feeding and Weaning Healthy and Productive Dairy Calves. Accessed Nov. 5, 2017. https://www.aphis.usda.gov/animal_health/ nahms/dairy/downloads/bamn/BAMN17_GuideFeeding.pdf.

Canadian Council On Animal Care. 2009. The care and use of farm animals in research, teaching and testing. CCAC, Ottawa, ON, Canada.

Chapple, R. S., and J. J. Lynch. 1986. Behavioural factors modifying acceptance of supplementary foods by sheep. Res. Dev. Agric. $3: 113-120$.

Costa, J. H. C., R. R. Daros, M. A. G. von Keyserlingk, and D. M. Weary. 2014. Complex social housing reduces food neophobia in dairy calves. J. Dairy Sci. 97:7804-7810. https://doi.org/10.3168/ jds.2014-8392.

Costa, J. H. C., R. K. Meagher, M. A. G. von Keyserlingk, and D. M. Weary. 2015. Early pair housing increases solid feed intake and weight gains in dairy calves. J. Dairy Sci. 98:6381-6386. https:// doi.org/10.3168/jds.2015-9395.

de Passillé, A. M., T. F. Borderas, and J. Rushen. 2011. Weaning age of calves fed a high milk allowance by automated feeders: Effects on feed, water, and energy intake, behavioral signs of hunger, and weight gains. J. Dairy Sci. 94:1401-1408. https://doi.org/10.3168/ jds.2010-3441.

de Passillé, A. M., and J. Rushen. 2012. Adjusting the weaning age of calves fed by automated feeders according to individual intakes of solid feed. J. Dairy Sci. 95:5292-5298. https://doi.org/10.3168/ jds.2012-5521.

de Passillé, A. M., and J. Rushen. 2016. Using automated feeders to wean calves fed large amounts of milk according to their ability to eat solid feed. J. Dairy Sci. 99:3578-3583. https://doi.org/10 $.3168 /$ jds.2015-10259.

de Paula Vieira, A., V. Guesdon, A. M. de Passillé, M. A. G. von Keyserlingk, and D. M. Weary. 2008. Behavioural indicators of hunger in dairy calves. Appl. Anim. Behav. Sci. 109:180-189. https://doi .org/10.1016/j.applanim.2007.03.006. de Paula Vieira, A., M. A. G. von Keyserlingk, and D. M. Weary. 2012. Presence of an older weaned companion influences feeding behavior and improves performance of dairy calves before and after weaning from milk. J. Dairy Sci. 95:3218-3224. https://doi .org/10.3168/jds.2011-4821.

Dennis, T. S., F. X. Suarez-Mena, T. M. Hill, J. D. Quigley, R. L. Schlotterbeck, and L. Hulbert. 2018b. Effect of milk replacer feeding rate, age at weaning, and method of reducing milk replacer to weaning on digestion, performance, rumination, and activity in dairy calves to 4 months of age. J. Dairy Sci. 101:268-278. https:/ /doi.org/10.3168/jds.2017-13692.

Dennis, T. S., F. X. Suarez-Mena, T. M. Hill, J. D. Quigley, R. L. Schlotterbeck, R. N. Klopp, G. J. Lascano, and L. Hulbert. 2018a. Effects of gradual and later weaning ages when feeding high milk replacer rates on growth, textured starter digestibility, and behavior in Holstein calves from 0 to 4 months of age. J. Dairy Sci. 101:9863-9875. https://doi.org/10.3168/jds.2018-15319.

Eckert, E., H. E. Brown, K. E. Leslie, T. J. DeVries, and M. A. Steele. 2015. Weaning age affects growth, feed intake, gastrointestinal development, and behavior in Holstein calves fed an elevated plane of nutrition during the preweaning stage. J. Dairy Sci. 98:6315-6326. https://doi.org/10.3168/jds.2014-9062.

Frieten, D., C. Gerbert, C. Koch, G. Dusel, K. Eder, E. Kanitz, J. M. Weitzel, and H. M. Hammon. 2017. Ad libitum milk replacer feeding, but not butyrate supplementation, affects growth performance as well as metabolic and endocrine traits in Holstein calves. J. Dairy Sci. 100:6648-6661. https://doi.org/10.3168/jds.2017-12722.

Geiger, A. J., C. L. M. Parsons, R. E. James, and R. M. Akers. 2016. Growth, intake, and health of Holstein heifer calves fed an enhanced preweaning diet with or without postweaning exogenous estrogen. J. Dairy Sci. 99:3995-4004. https://doi.org/10.3168/jds .2015-10405.

Gelsinger, S. L., A. J. Heinrichs, and C. M. Jones. 2016. A metaanalysis of the effects of preweaned calf nutrition and growth on first-lactation performance. J. Dairy Sci. 99:6206-6214. https:// doi.org/10.3168/jds.2015-10744.

Greenwood, R. H., J. L. Morrill, and E. C. Titgemeyer. 1997. Using dry feed intake as a percentage of initial body weight as a weaning criterion. J. Dairy Sci. 80:2542-2546. https://doi.org/10.3168/jds .S0022-0302(97)76208-8.

Heinrichs, A. J., and B. S. Heinrichs. 2011. A prospective study of calf factors affecting first-lactation and lifetime milk production and age of cows when removed from the herd. J. Dairy Sci. 94:336-341. https://doi.org/10.3168/jds.2010-3170.

Hepola, H. 2003. Milk feeding systems for dairy calves in groups: Effects on feed intake, growth and health. Appl. Anim. Behav. Sci. 80:233-243. https://doi.org/10.1016/S0168-1591(02)00214-9.

Hill, T. M., H. G. Bateman, J. M. Aldrich, and R. L. Schlotterbeck. 2010. Effect of milk replacer program on digestion of nutrients in dairy calves. J. Dairy Sci. 93:1105-1115. https://doi.org/10.3168/ jds.2009-2458.

ISO. (International Organization for Standardization). 2013. ISO 9622|IDF 141:2013. Milk and liquid milk products -- Guidelines for the application of mid-infrared spectrometry. https://www.iso .org/standard/56874.html.

Jasper, J., and D. M. Weary. 2002. Effects of ad libitum milk intake on dairy calves. J. Dairy Sci. 85:3054-3058. https://doi.org/10.3168/ jds.S0022-0302(02)74391-9.

Jensen, M. B. 2006. Computer-controlled milk feeding of group-housed calves: The effect of milk allowance and weaning type. J. Dairy Sci. 89:201-206. https://doi.org/10.3168/jds.S0022-0302(06)72084-7.

Kertz, A. F., and J. R. Loften. 2013. Review: A historical perspective of specific milk-replacer feeding programs in the United States and effects on eventual performance of Holstein dairy calves. Prof. Anim. Sci. 29:321-332. https://doi.org/10.15232/S1080 -7446(15)30245-X.

Khan, M. A., A. Bach, D. M. Weary, and M. A. G. von Keyserlingk. 2016. Invited review: Transitioning from milk to solid feed in dairy heifers. J. Dairy Sci. 99:885-902. https://doi.org/10.3168/jds.2015 -9975 . 
Khan, M. A., H. J. Lee, W. S. Lee, H. S. Kim, K. S. Ki, T. Y. Hur, G. H. Suh, S. J. Kang, and Y. J. Choi. 2007a. Structural growth, rumen development, and metabolic and immune responses of holstein male calves fed milk through step-down and conventional methods. J. Dairy Sci. 90:3376-3387. https://doi.org/10.3168/jds 2007-0104.

Khan, M. A., H. J. Lee, W. S. Lee, H. S. Kim, S. B. Kim, K. S. Ki, J. K. Ha, H. G. Lee, and Y. J. Choi. 2007b. Pre- and postweaning performance of Holstein female calves fed milk through step-down and conventional methods. J. Dairy Sci. 90:876-885. https://doi .org/10.3168/jds.S0022-0302(07)71571-0.

Khan, M. A., D. M. Weary, and M. A. G. von Keyserlingk. 2011. Invited review: Effects of milk ration on solid feed intake, weaning, and performance in dairy heifers. J. Dairy Sci. 94:1071-1081. https://doi.org/10.3168/jds.2010-3733.

Khani, M., F. Ahmadi, M. Ariana, S. Omidian, S. Sharifi, M.H. Ghaffari, and H. Beiranvand. 2017. Performance of Holstein calves receiving equal quantities of milk at fixed or variable amounts per day during milk-feeding period. Animal 11:1737-1744. https://doi .org/10.1017/S1751731117000647.

Knauer, W. A., S. M. Godden, A. Dietrich, and R. E. James. 2017. The association between daily average feeding behaviors and morbidity in automatically fed group-housed preweaned dairy calves. J. Dairy Sci. 100:5642-5652. https://doi.org/10.3168/jds.2016-12372.

Kung, L., S. Demarco, L. N. Siebenson, E. Joyner, G. F. W. Haenlein, and R. M. Morris. 1997. An evaluation of two management systems for rearing calves fed milk replacer. J. Dairy Sci. 80:2529-2533.

Meale, S. J., L. N. Leal, J. Martín-Tereso, and M. A. Steele. 2015. Delayed weaning of Holstein bull calves fed an elevated plane of nutrition impacts feed intake, growth and potential markers of gastrointestinal development. Anim. Feed Sci. Technol. 209:268-273. https://doi.org/10.1016/j.anifeedsci.2015.08.008.

Mirzaei, M., N. Dadkhah, B. Baghbanzadeh-Nobari, A. Agha-Tehrani, M. Eshraghi, M. Imani, R. Shiasi-Sardoabi, and M. H. Ghaffari. 2018. Effects of preweaning total plane of milk intake and weaning age on intake, growth performance, and blood metabolites of dairy calves. J. Dairy Sci. 101:4212-4220. https://doi.org/10.3168/jds .2017-13766.

Montoro, C., I. Ipharraguerre, and A. Bach. 2011. Effect of flavoring a starter in a same manner as a milk replacer on intake and performance of calves. Anim. Feed Sci. Technol. 164:130-134. https:/ /doi.org/10.1016/j.anifeedsci.2010.11.023.

Morrill, J. L., and A. D. Dayton. 1978. Effect of feed flavor in milk and calf starter on feed consumption and growth. J. Dairy Sci. 61:229-232. https://doi.org/10.3168/jds.S0022-0302(78)83582-6.

Neave, H. W., J. H. Costa, D. M. Weary, and M. A. G. von Keyserlingk. 2018. Personality is associated with feeding behavior and performance in dairy calves. J. Dairy Sci. 101:7437-7449. https:// doi.org/10.3168/jds.2017-14248.

Nielsen, P. P., M. B. Jensen, and L. Lidfors. 2008. Milk allowance and weaning method affect the use of a computer controlled milk feeder and the development of cross-sucking in dairy calves. Appl. Anim. Behav. Sci. 109:223-237. https://doi.org/10.1016/j.applanim.2007 .01 .015 .

NRC. 2001. Nutrient Requirements of Dairy Cattle. 7th rev. ed. Natl. Acad. Press, Washington, DC.
Omidi-Mirzaei, H., M. Khorvash, G. R. Ghorbani, B. Moshiri, M. Mirzaei. A. Pezeshki, and M. H. Ghaffari. 2015. Effects of the step-up/step-down and step-down milk feeding procedures on the performance, structural growth, and blood metabolites of Holstein dairy calves. J. Dairy Sci. 98:7975-7981. https://doi.org/10.3168/ jds.2014-9260.

Raeth-Knight, M., H. Chester-Jones, S. Hayes, J. Linn, R. Larson, D. Ziegler, B. Ziegler, and N. Broadwater. 2009. Impact of conventional or intensive milk replacer programs on Holstein heifer performance through six months of age and during first lactation. J. Dairy Sci. 92:799-809. https://doi.org/10.3168/jds.2008-1470.

Reinhardt, V., and A. Reinhardt. 1981. Natural sucking performance and age of weaning in zebu cattle (Bos indicus). J. Agric. Sci. 96:309-312. https://doi.org/10.1186/1751-0147-53-28.

Rosenberger, K., J. H. C. Costa, H. W. Neave, M. A. G. von Keyserlingk, and D. M. Weary. 2017. The effect of milk allowance on behavior and weight gains in dairy calves. J. Dairy Sci. 100:504-512. https://doi.org/10.3168/jds.2016-11195.

Roth, B. A., E. Hillmann, M. Stauffacher, and N. M. Keil. 2008. Improved weaning reduces cross-sucking and may improve weight gain in dairy calves. Appl. Anim. Behav. Sci. 111:251-261. https:/ /doi.org/10.1016/j.applanim.2007.06.007.

Roth, B. A., N. M. Keil, L. Gygax, and E. Hillmann. 2009. Influence of weaning method on health status and rumen development in dairy calves. J. Dairy Sci. 92:645-656. https://doi.org/10.3168/ jds.2008-1153.

Rutten, C. J., A. G. J. Velthuis, W. Steeneveld, and H. Hogeveen. 2013. Invited review: Sensors to support health management on dairy farms. J. Dairy Sci. 96:1928-1952. https://doi.org/10.3168/ jds.2012-6107.

Steele, M. A., J. H. Doelman, L. N. Leal, F. Soberon, M. Carson, and J. A. Metcalf. 2017. Abrupt weaning reduces postweaning growth and is associated with alterations in gastrointestinal markers of development in dairy calves fed an elevated plane of nutrition during the preweaning period. J. Dairy Sci. 100:5390-5399. https:// doi.org/10.3168/jds.2016-12310.

Sweeney, B. C., J. Rushen, D. M. Weary, and A. M. de Passillé. 2010. Duration of weaning, starter intake, and weight gain of dairy calves fed large amounts of milk. J. Dairy Sci. 93:148-152. https:/ /doi.org/10.3168/jds.2009-2427.

Van Soest, P. J., J. B. Robertson, and B. A. Lewis. 1991. Methods for dietary fiber, neutral detergent fiber, and nonstarch polysaccharides in relation to animal nutrition. J. Dairy Sci. 74:3583-3597. https://doi.org/10.3168/jds.S0022-0302(91)78551-2.

Windeyer, M. C., K. E. Leslie, S. M. Godden, D. C. Hodgins, K. D Lissemore, and S. J. LeBlanc. 2014. Factors associated with morbidity, mortality, and growth of dairy heifer calves up to 3 months of age. Prev. Vet. Med. 113:231-240. https://doi.org/10.1016/j .prevetmed.2013.10.019.

Zanton, G. I., and A. J. Heinrichs. 2005. Meta-analysis to assess effect of prepubertal average daily gain of Holstein heifers on firstlactation production. J. Dairy Sci. 88:3860-3867. https://doi.org/ 10.3168/jds.S0022-0302(05)73071-X. 